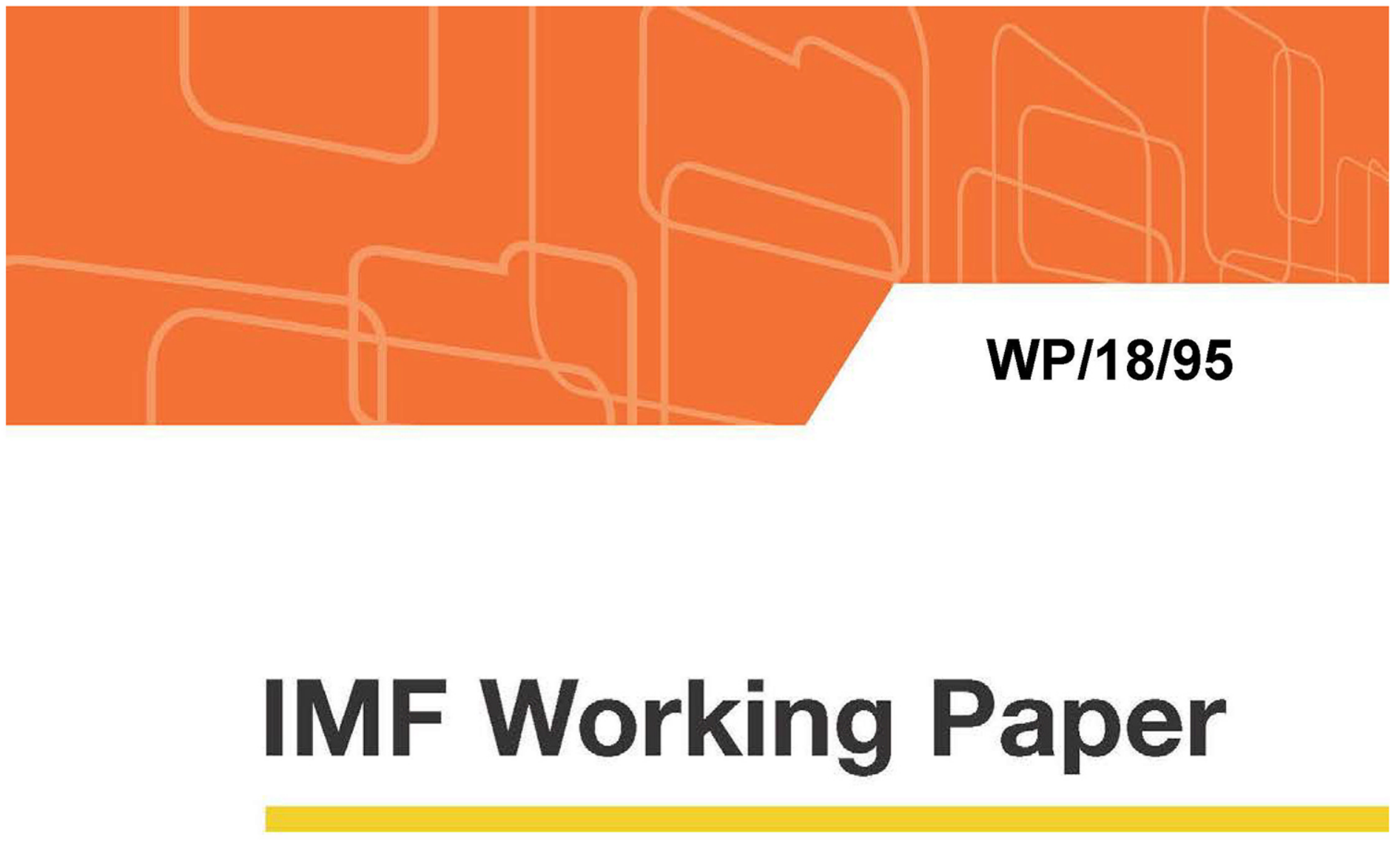

\title{
Instruments, Investor Base, and Recent Developments in the Malaysian Government Bond Market
}

by Yinqiu Lu and Dmitry Yakovlev

IMF Working Papers describe research in progress by the author(s) and are published to elicit comments and to encourage debate. The views expressed in IMF Working Papers are those of the author(s) and do not necessarily represent the views of the IMF, its Executive Board, or IMF management. 


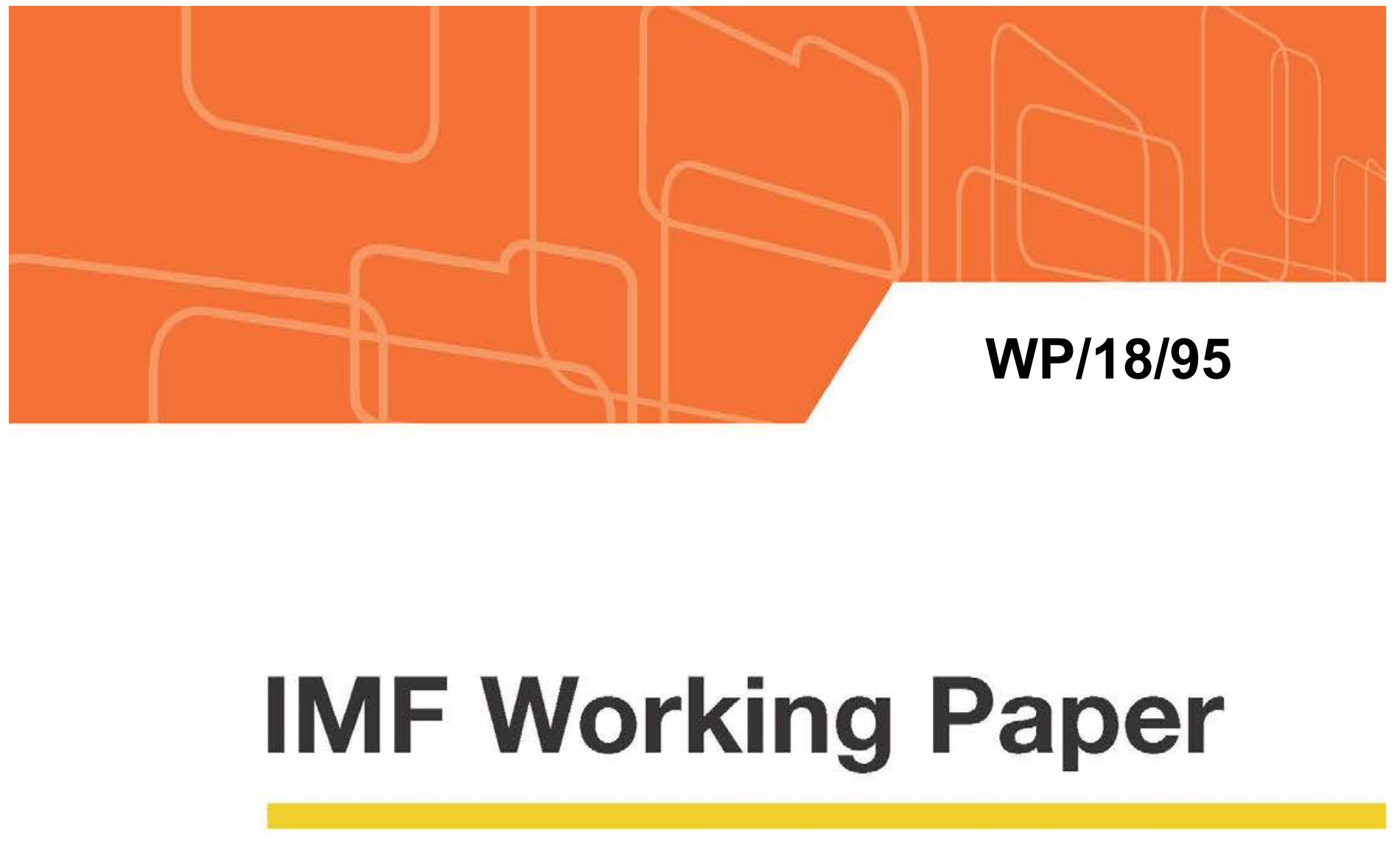

\section{Instruments, Investor Base, and Recent Developments in the Malaysian Government Bond Market}

by Yinqiu Lu and Dmitry Yakovlev

IMF Working Papers describe research in progress by the author(s) and are published to elicit comments and to encourage debate. The views expressed in IMF Working Papers are those of the author(s) and do not necessarily represent the views of the IMF, its Executive Board, or IMF management.

$$
\text { I N T ER N A T I O N A L M O NETAR Y FU N D }
$$




\title{
IMF Working Paper
}

Strategy, Policy, and Review Department

\section{Instruments, Investor Base, and Recent Developments in the Malaysian Government Bond Market}

\section{Prepared by Yinqiu Lu and Dmitry Yakovlev ${ }^{1}$}

Authorized for distribution by Martin Kaufman

April 2018

IMF Working Papers describe research in progress by the author(s) and are published to elicit comments and to encourage debate. The views expressed in IMF Working Papers are those of the author(s) and do not necessarily represent the views of the IMF, its Executive Board, or IMF management.

\begin{abstract}
Foreign holdings of Malaysian local currency (LCY) government bonds have increased since the global financial crisis. By exploring the micro-level bank by bank and fund by fund data, we are able to shed light on the key features of the LCY government bonds including their investor base. The data suggest that to gain exposure to the Malaysian credit, holding cash bonds is generally only one part of the strategy of foreign investors and in many cases FX derivatives are involved. The availability of an efficient FX derivatives market could help to attract a wider range of foreign investors and enrich the bond market. Meanwhile, the analysis of the risk related to the foreign ownership ideally could also cover the role of derivatives. The analsyis also allows us to conclude that despite the importance of foreign investors, domestic participants, as the core investor base, could help to ensure the stability and proper functioning of the bond market.
\end{abstract}

JEL Classification Numbers: E43; E44; F30; G15

Keywords: local currency government bonds; FX derivatives; Malaysia

Author’s E-Mail Address: ylu@imf.org; and d.yakovlev@,bloomberg.net

\footnotetext{
${ }^{1}$ This paper has benefited from comments from Varapat Chensavasdijai, Kay Chung, David Grigorian, Martin Kaufman, Peter Lindner, and colleagues from Bank Negara Malaysia; and excellent research assistance from Viacheslav Ilin. We remain responsible for any remaining errors.
} 
I. Introduction $\underline{4}$

II. The Malaysian Government Fixed-Income Market and the Role of Domestic Banks $\underline{5}$

III. Investment Strategies of the Foreign Investment Funds $\underline{14}$

IV. Factors Influencing the Malaysia Weight in GBI-EM Indices $\underline{22}$

V. The MGS Market Sell-Off $\underline{25}$

VI. Conclusion $\underline{27}$

Boxes

1. Bank Data 13

2. Templeton GBF's Exposure to MYR Bonds and FX Forwards $\underline{20}$

3. Spectrum of Investment Strategies: Currency Overlay and Yield Enhancement

4. Adjustment to the New Format of Presentation of the Breakdown of New MSG Holders

Annex

1. Synthetic Exposure to Malaysian Fixed-Income Instruments $\underline{30}$

References $\underline{29}$ 


\section{INTRODUCTION}

In recent years, the impact of ample global liquidity on both advanced and emerging economies (EMs) has attracted considerable attention (e.g., Shin, 2012; and IMF, 2014). One financial instrument that has channeled the ample global liquidity into the EMs, pulled by improved fundamentals of EMs, is the local currency (LCY) government securities. Much has been written on the roles of foreign investors in the EM LCY government bond markets. Some analyze the impact of the foreign ownership on the level and volatility of bond yields (e.g., Peiris, 2010; and Ebeke and Lu, 2015); some explore factors that influence the foreign demand for the LCY government securities (e.g., Arslanalp and Tsuda, 2012 and 2015); and some investigate the roles of foreign investors in helping develop the domestic bond market (e.g., Lu and Yakovlev, 2017). However, relatively little has been written on the micro-level players that have helped to channel global liquidity into the EM fixed-income markets.

The fixed-income government securities market in Malaysia has provided us an opportunity to explore the roles of the micro-level players. The data we rely on are the detailed balance sheets of individual banks in Malaysia and individual foreign investment funds that hold Malaysian LCY government securities.

The Malaysian government securities (MGS), Shariah-compliant Islamic government bonds - the Malaysian Government Investment Issue (MGII), and Bank Negara Malaysia $(\mathrm{BNM})$ bills are the key fixed-income instruments denominated in local currency (MYR) in Malaysia, which in total account for about 50 percent of GDP. When foreign investors purchase them, they bring global liquidity to Malaysia; and when they sell them and deposit the receipts abroad, global liquidity exits from Malaysia. The coexistence of the conventional and Islamic LCY government bonds in Malaysia provides us a unique angle through which we could investigate the roles of different types of Malaysian banks in channeling domestic and foreign liquidity into the fixed-income market. The existence of the short-term BNM bills - this instrument has been discontinued with a very small fraction of the stock remaining to date - allows us to analyze their role in channeling the short-term capital inflows and whether they could to some extent insulate the MGS and MGII markets from such inflows (Section II).

As Malaysian LCY government bonds demonstrate considerable foreign exchange (FX) volatility relative to low and stable yield, FX derivatives become indispensable for foreign investors. They are employed by investors not just to limit FX risks but also to efficiently obtain an exposure to the short-term MYR FX risk or to execute a combination of interest rate and FX exposures that fit their investment strategies and risk outlooks. In this regard, even though FX derivatives are frequently netted out and largely cashless, and do not directly transmit global liquidity, the availability of an efficient FX derivatives market can attract a wider range of foreign investors and enrich the bond market through greater price discovery and liquidity. At the same time, as the associated cross-border liquidity flows are ultimately related to various financial instruments of different issuers with different credit quality (i.e., cash bonds and derivatives have different issuers with different credit qualities), the analysis of the risk related to the foreign ownership of LCY bonds ideally could cover not only 
investors' holdings of cash bonds but also other involved instruments such as derivatives (Section III).

The Malaysia's weights in the GBI-EM indices (i.e., Government Bond Index-Emerging Markets developed by J. P. Morgan) were cut recently. The weight in the GBI-EM GD index ("GD" stands for Global Diversified) declined from 10 percent on February 26, 2016 to 6 percent on August 31, 2017. Because bonds considered illiquid by J.P. Morgan are removed from the index, about one percentage point of the cut in the weight was due the downgrade in the liquidity status of some MGS, which J.P. Morgan attributed to the recent developments in the non-deliverable forward (NDF) markets (J.P. Morgan, 2017a). Nevertheless, the decline in the bond issuance in Malaysia relative to other EMs can explain most of the cut in the weight (Section IV).

During the bond sell-offs by foreign investors, as investors are able to change their exposure via both cash bonds and derivatives, the potential impact could be felt in the bond, FX, and derivatives markets. Therefore, an analysis on foreign positions in these markets as well as the potential counterparties to provide liquidity is important. When liquidity dries up during the bond sell-offs by foreign investors, we expect that domestically owned local banks would provide liquidity to purchase these bonds. This is indeed what had happened in Malaysia. In addition, the subsidiaries of the foreign banks were as active as local banks in purchasing these bonds. Immediately following the severe sell-offs, the role of domestic institutional investors turned out to be more limited compared to domestic banks, but their role in providing a stable and sizable demand for the bonds is fundamental in the medium- and longterm (Section V).

By looking at the micro-level data, we are able to shed light on the roles of the domestic banking system and foreign investment funds in the Malaysian LCY government bond market. The case of Malaysia suggests that a full spectrum of domestic fixed-income instruments, an efficient FX derivatives market, and a resilient domestic banking sector can play positive roles in helping to develop and stabilize the government bond market.

\section{The Malaysian Government FiXed-InCome MARKet And THE Role OF DOMESTIC BANKS}

\section{MGS and MGII}

The foreign holdings of MGS are high while their holdings of the Shariah-compliant MGII remain low. After a brief decline in the wake of the global financial crisis, the share of the foreign ownership of MGS reached a peak of 52 percent in October 2016 but has since declined to about 40 percent in mid-2017 (Figure 1). The foreign holdings of MGII increased from close to zero in 2012 to 8 percent in mid-2017 (Figure 2). 


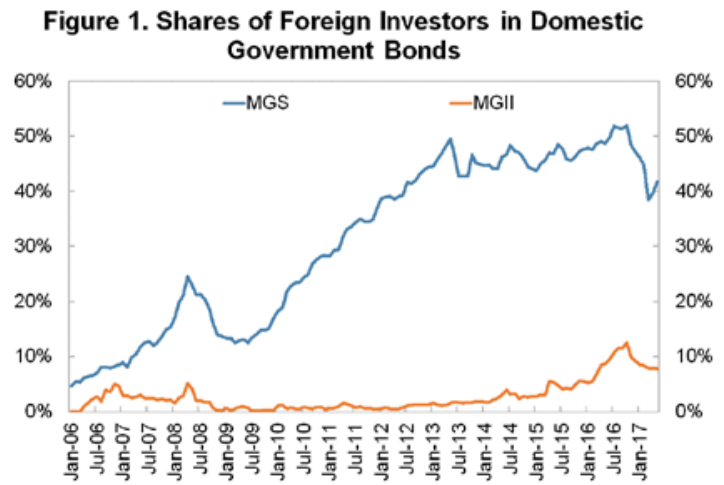

Sources: Haver; and authors' calculations.

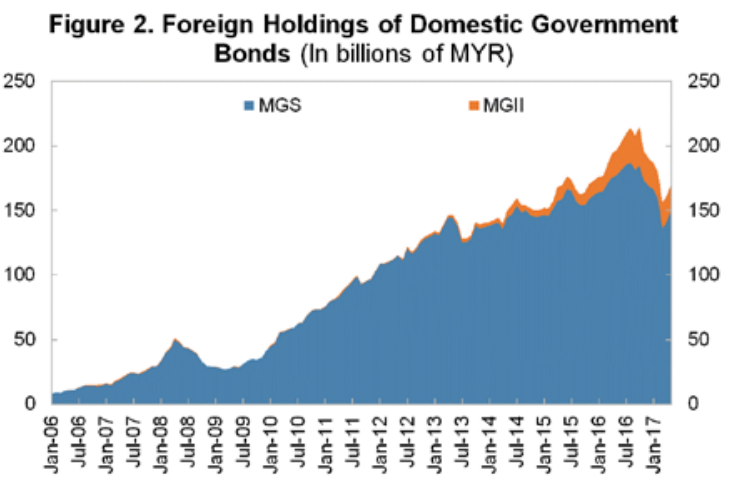

Sources: Haver; and authors' calculations.

This difference in the foreign holdings of bonds issued by the same sovereign is not uncommon. Foreign holdings often represent a high share of one segment of EM LCY bonds while having much limited presence in the remaining segments. For example, in Russia foreign investors used to dominate the tradable medium- to long-term government bonds (Lu and Yakovlev, 2017) (Figure 3). Similarly, in the case of Brazil, foreign investors at some point represented more than 70 percent of the longer term fixed-rate bonds (NTN-F) (Figure 4). In the case of Poland, in June 2017 foreign investors represented up to 80 percent of the outstanding amount of a few select bonds (Figure 5), and moreover their total position was largely concentrated in a small number of bonds. For example, 3 bonds accounted for close to one-third of the total foreign holdings (Figure 6).

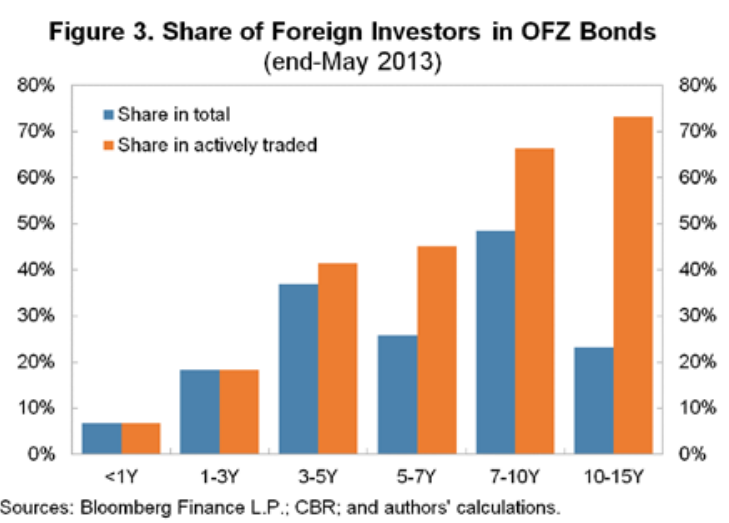

Figure 5. Poland: Share of Foreign Investors in Individual

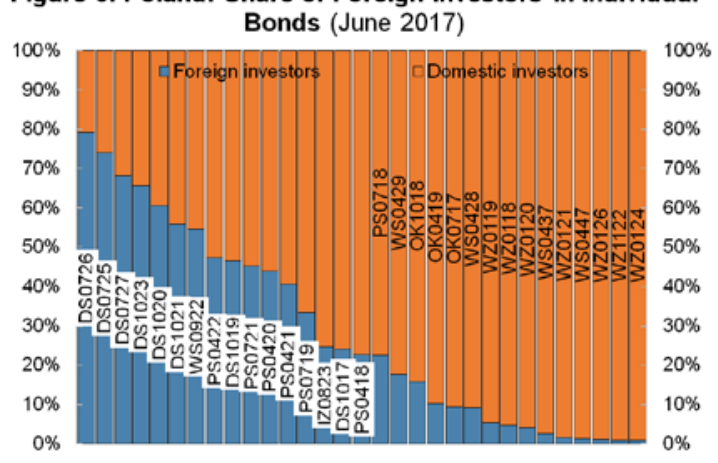

Sources: Ministry of Finance: and authors' calculations.

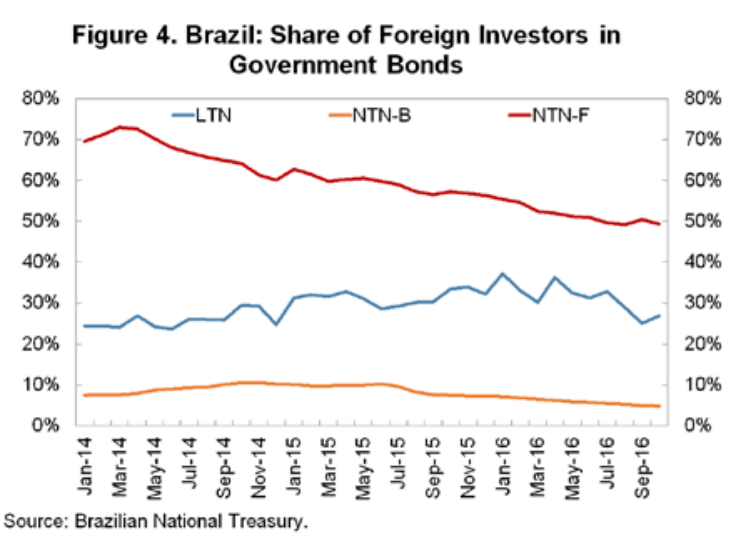

Figure 6. Poland: Concentration of Total Foreign Holdings

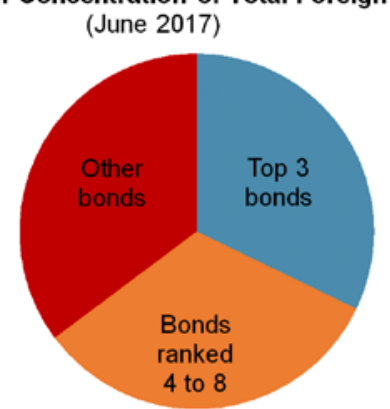

Sources: Ministry of Finance; and authors' calculations. 
While for these countries the difference in holdings could be explained by the differences in the levels of bond duration and liquidity, in the case of Malaysia, MGS and MGII are very similar despite their difference in the structure of issuance. They all have bullet and fixedcoupon rate structure, have similar supply of maturities (Figure 7), comparable turnover rates in the secondary market (Figure 8), and the secondary market trading is spread across maturities (Figure 9).

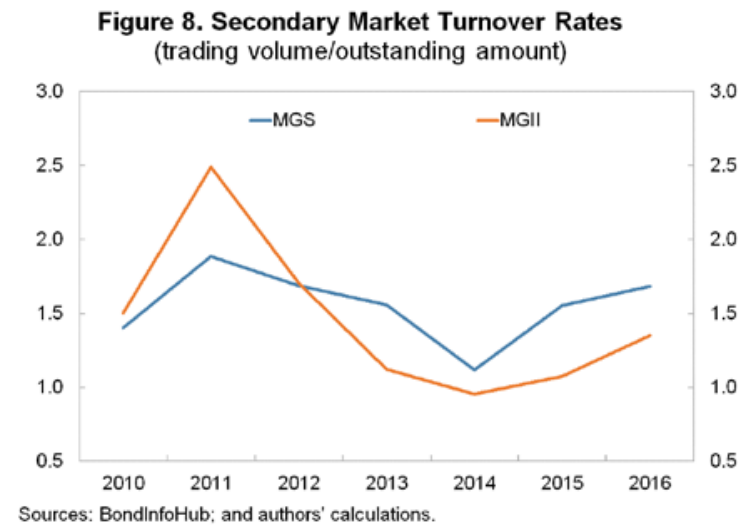

Figure 7. Maturity Breakdown of Outstanding Bonds

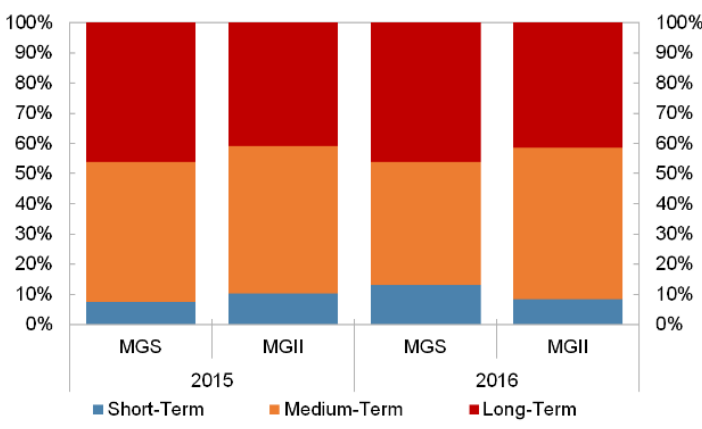

Sources: Bloomberg Finance L.P.; and authors' calculations.

Figure 9. Trading-volume-weighted Time to Maturity (Year)

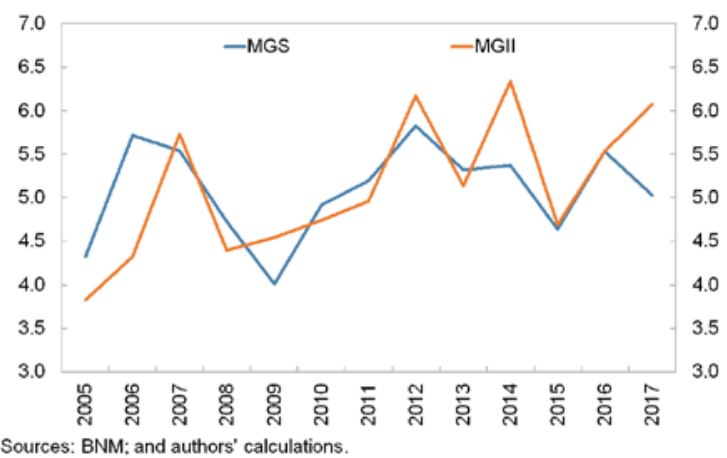

One possible explanation for the difference in holdings is the difference in the domestic core investor base for MGS and MGII. Domestic banks (local banks and subsidiaries of foreign banks; and commercial and Islamic banks) are the important holders of both types of bonds but the importance differs by bank type. ${ }^{2,3}$ They hold about 30 percent and 40 percent of domestically owned MGS and MGII (Figures 10-11). Commercial banks (both local and foreign ones) have allocations to both MGS and MGII with foreign banks' holdings more biased towards MGS. Islamic banks (both local and foreign ones) tend to allocate almost exclusively to MGII (Figure 12). Consequently, MGS are held mostly by the commercial banks while MGII by both the commercial and Islamic banks (Figure 13).

\footnotetext{
${ }^{2}$ See Box 1 for the methodology of compiling bank data.

${ }^{3}$ To observe the composition of these instruments in banks' portfolios, data at end-2013 are used for some charts, as at that point, both domestic banks and foreign investors had significant allocations to MGS/MGII and $\mathrm{BNM}$ /Treasury bills. BNM bill issuance has been discontinued with a very small fraction of the stock remaining to date. BNM have recently introduced Bank Negara Interbank Bills (BNIBs) in ringgit and foreign currency, which are made available to onshore banks through auctions to manage ringgit and foreign currency liquidity (IMF, 2018).
} 
Figure 10. MGS Investor Base

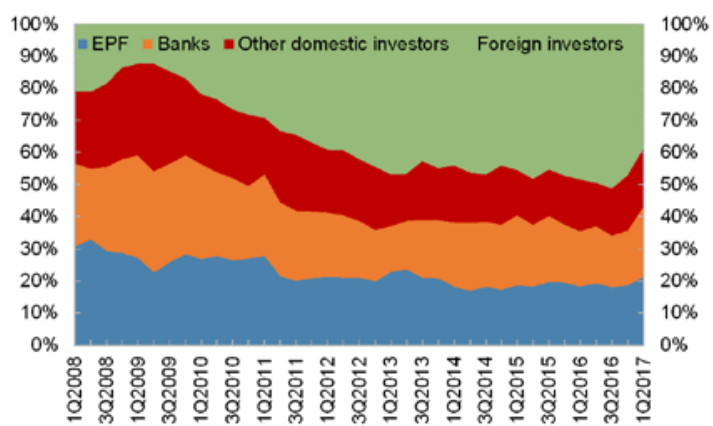

Sources: Haver; and authors' calculations.

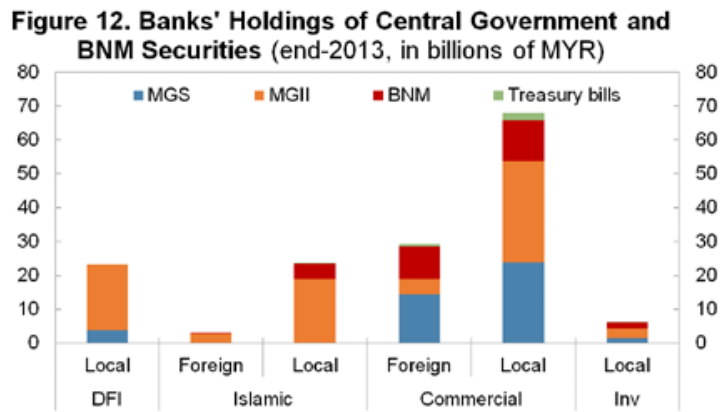

Sources: Banks' financial reports; and authors' calculations.

Note: "DFI" stands for development financial institutions; and "Inv" stands for

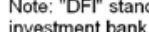

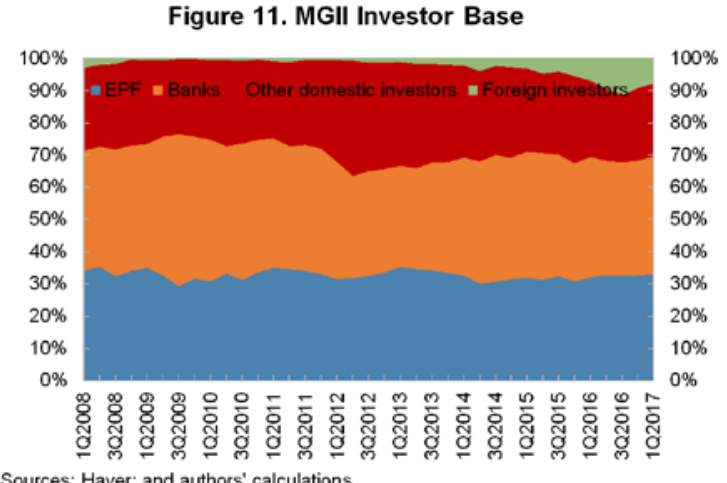

Sources: Haver; and authors' calculations.

Figure 13. Breakdown of Securities Holdings by Bank Type (end-2013, in billions of MYR)

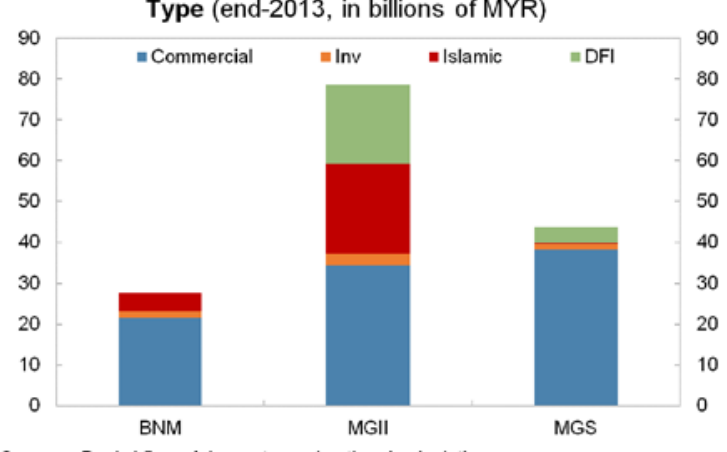

Sources: Banks' financial reports; and authors' calculations.

The roles of banks in the secondary markets also differ between MGS and MGII (Figures 14-15). First, the top ranking for the MGS secondary market has been largely dominated by the subsidiaries of global investment banks (GIB-subs), e.g., Citibank, HSBC, and J.P. Morgan; while the top ranking for the MGII market is almost exclusively consisted of local banks. Second, there is a disconnection between the trading and holding of MGS. Most of the top ranked banks in the MGS secondary market are not those with the largest holdings of MGS. However, this is not the case for MGII, as the set of top ranked banks in the secondary market is broadly the same set of the largest holders of MGII.

Figure 14. Holdings of MGS by Banking Groups (end-2013, in billions of MYR)

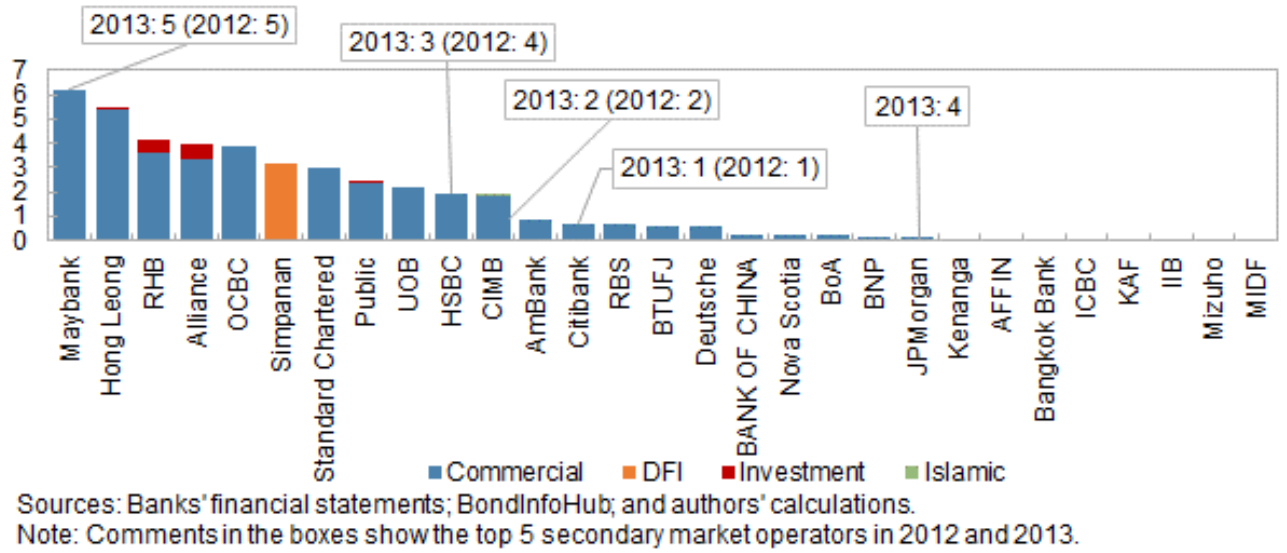


Figure 15. Holdings of MGII by Banking Groups (end-2013, in billions of MYR)

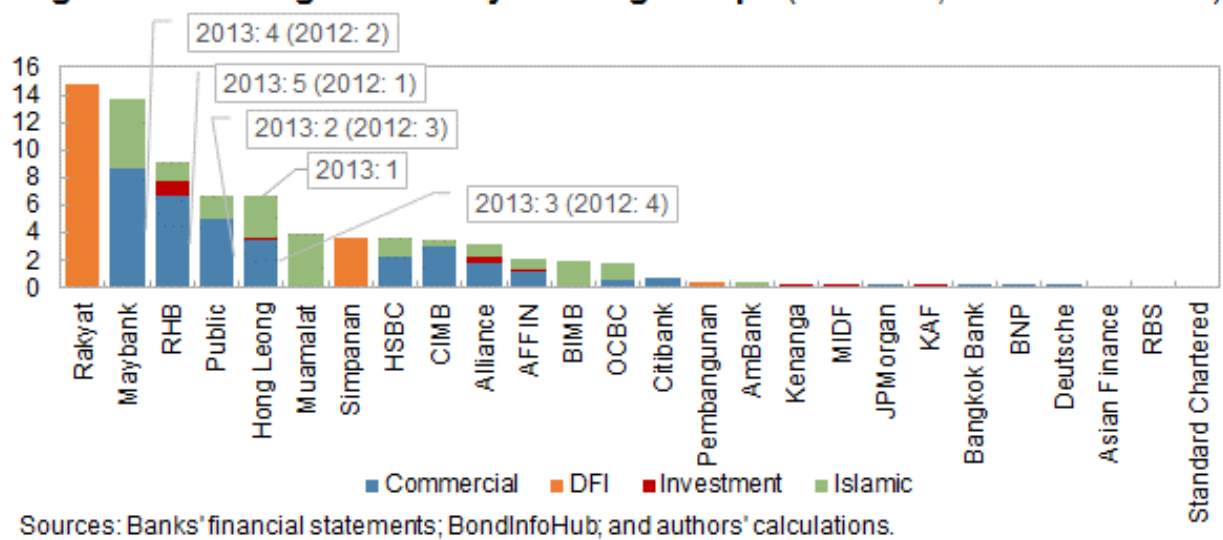

Note: Comments in the boxes show the top 5 secondary market operators in 2012 and 2013.

The role of the GIB-subs may explain the disconnection between the trading and holding of MGS. The GIB-subs often act as the commission brokers or principals in assisting foreign investors in executing their MGS trading. They have a unique competitive advantage of a large network of global clients. Their balance sheets are often geared towards dealing with low credit-risk instruments (such as government bonds, positions at central banks, or interbank lending) or derivatives while the local banks have more expertise in managing domestically sourced credit risk (such as loans and domestic corporate bonds) (Figure 16). The interactions between the two secondary markets and the key

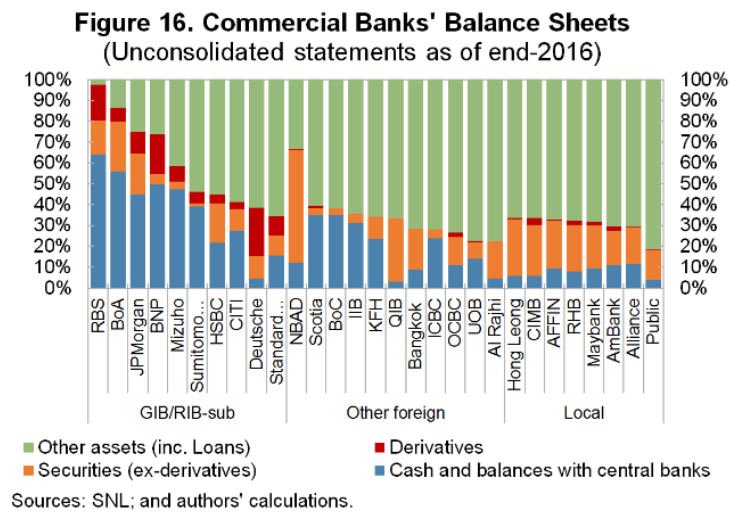
players can be described in Figure 17.

Figure 17. Interactions between MGS and MGII Secondary Markets

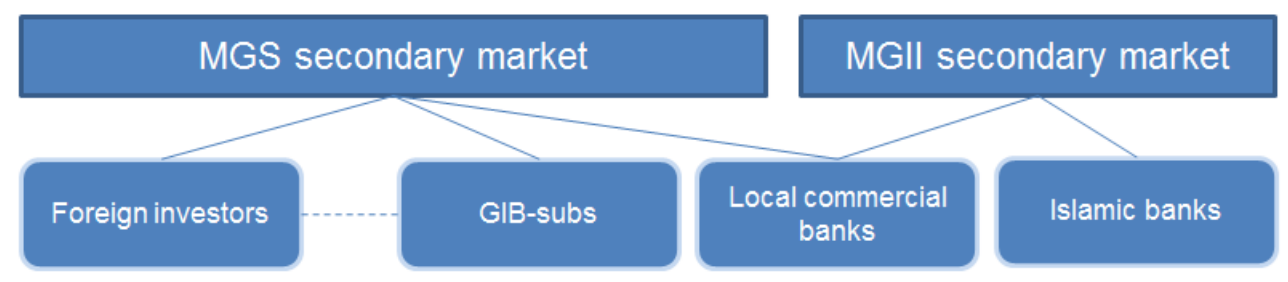

Another reason for the disconnection between the trading and holding of MGS could be that many local banks investing in MGS have substantially longer-term investment horizons. A large portion of their holdings in government securities are classified as "Held-to-Maturity" (HTM) (Figure 18) and thus are removed from the secondary market. Overall, from the assetliability management perspective, domestic bonds are the main suppliers of the longer-term duration risk to the local banks, as a majority of them carry fixed-rate coupon while most of bank loans are in variable/floating rate terms (e.g., the balance sheet of Maybank, Figure 19). 
The much larger participation of foreign investors in the MGS market relative to the MGII market could probably be one of the explanations for the difference in the valuation between these two. Generally, the yields of MGII are 5-15 bps higher than those of MGS with similar maturity, and the MGII yields are essentially the ceiling for the MGS yields. It is likely that in a calm or booming market, the additional marginal demand from foreign investors could help to lower the bond yields relative to those predominantly owned by domestic investors.
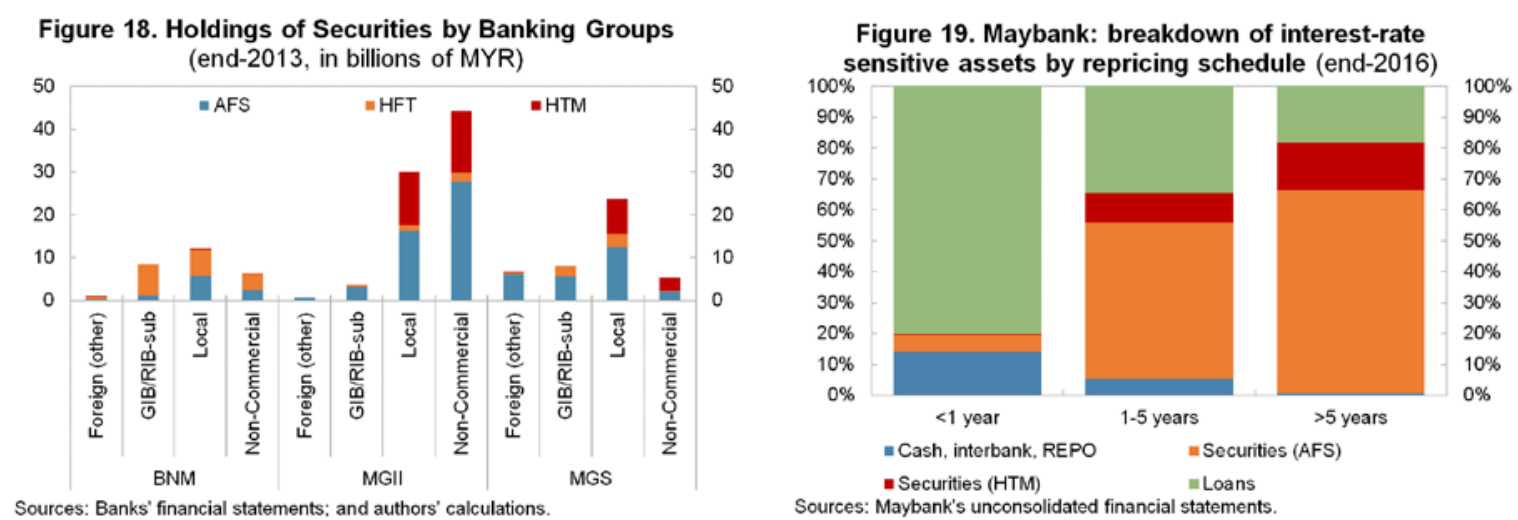

This role of foreign investors can also be attested in the episode of a bond market sell-off. During a sell-off, some foreign investors would sell their positions even with a substantial discount, especially if the shock is accompanied by the currency depreciation. For example, the convergence of the Russian offshore and onshore sovereign bonds took place during the euro area crisis (Figure 20). In such a case, the yields on bonds with large foreign ownership may temporarily exceed those of the mostly domestically owned ones before domestic investors step in to pick up the positions sold by the foreigners. This is what happened to the yields of MGS and MGII during the acute episode of the 2013 taper tantrum (Figure 21).
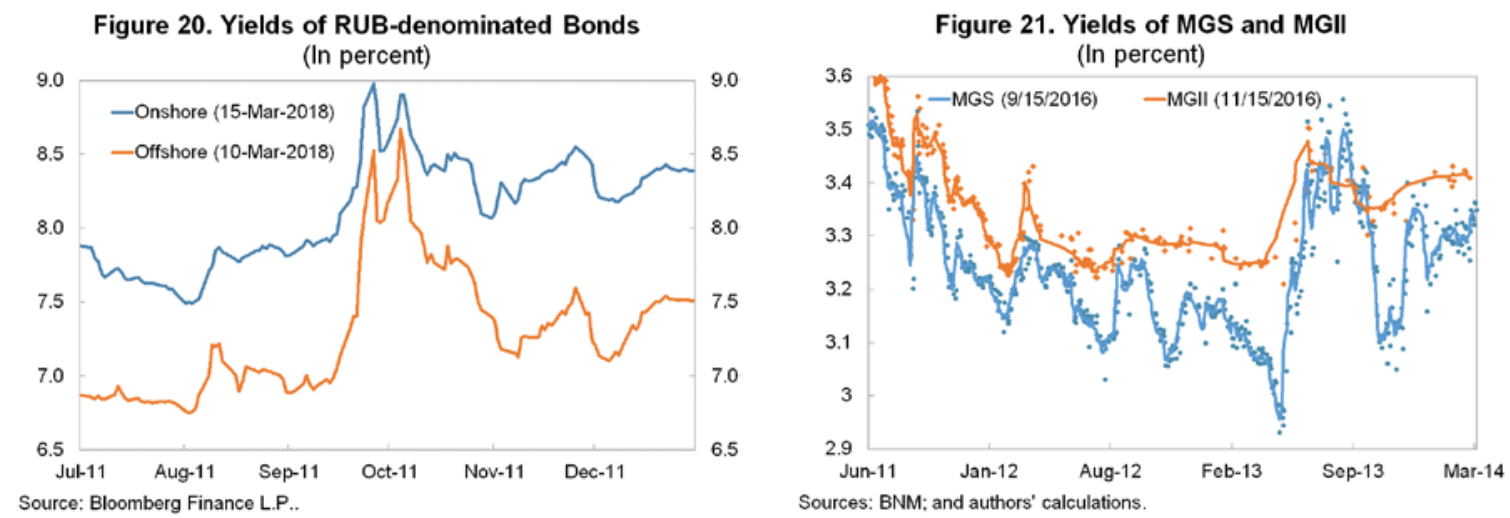

The magnitude of the divergence between the MGS and MGII yields is expected to narrow due to new measures introduced by BNM to promote the liquidity of the MGII market (e.g., to include MGII in the eligible securities for short-selling transactions (BNM, 2017)), and increased foreign demand for MGII. 


\section{BNM bills}

Short-term instruments could generally supplement the medium- and long-term instruments in fulfilling foreign investors' investment strategies. ${ }^{4}$ As investment strategies could span from the shortest-term carry trades to strategic allocations with a long-term horizon, the existence of only one type of domestic instruments may not efficiently serve the diverse demand from foreign investors. A combination of different instruments would be able to meet the demand of different types of foreign investors or different strategies of one investor, and allow the domestic financial system to better absorb the often-volatile portfolio inflows.

Such a split in foreign interest can be observed in many EM markets. As we can see from Figures 22-25, foreign holdings in the medium- and long-term government bonds were generally on an uptrend; while this was not the case for their holdings in the short-term instruments, which seemed to be more volatile and could swing from almost half of the holdings of longer-term bonds to close to zero, though part of the volatility could be due to the generally more volatile stock of short-term instruments.

As the short-term instruments are employed mostly for short-term speculative strategies by investors, they typically have much more secondary market turnover and could help to absorb short-term speculative capital flows. For example, in Hungary during the 2011-12 period when the domestic and external uncertainties were high, the secondary market turnover of the treasury bills almost tripled mainly due to the operations by foreign investors (Figure 26), while the secondary market activities of government bonds increased less significantly (Figure 27). In the case of Malaysia, the secondary market turnover of the conventional BNM bills was larger relative to their outstanding stock compared to those of MGS and MGII during 2010-14, a period when foreign participation in BNM bills was high (Figures 28-29). In other words, the existence of the BNM bill market has helped to absorb the short-term speculative capital inflows attracted by the perspective of the MYR appreciation and partially insulate the MGS and MGII markets from these inflows despite that the BNM bill market may have encouraged more short-term flows in the past (as BNM bill issuance has been discontinued).

\footnotetext{
${ }^{4}$ Central bank bills have differences other than maturity from sovereign bonds, such as credit risks and purpose and frequency of issuance. These differences usually would not prevent foreigners from investing in them.
} 
Figure 22. Malaysia: Foreign Holdings of Short-term and Medium- and Long-term Instruments (In billions of MYR)

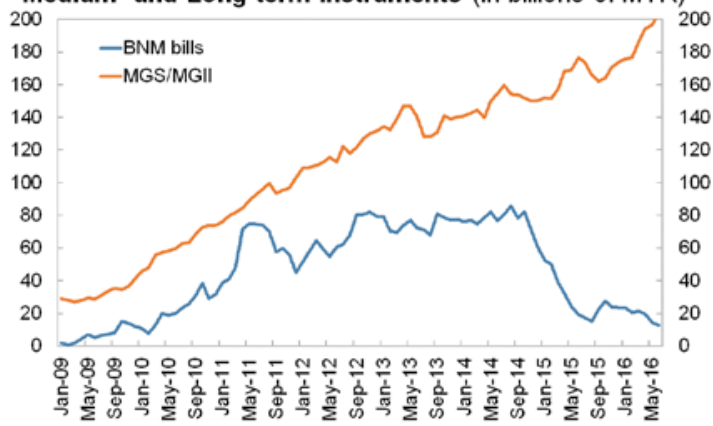
Source: Haver.

Figure 24. Poland: Foreign Holdings of Short-term and Medium- and Long-term Instruments (In billions of PLN)

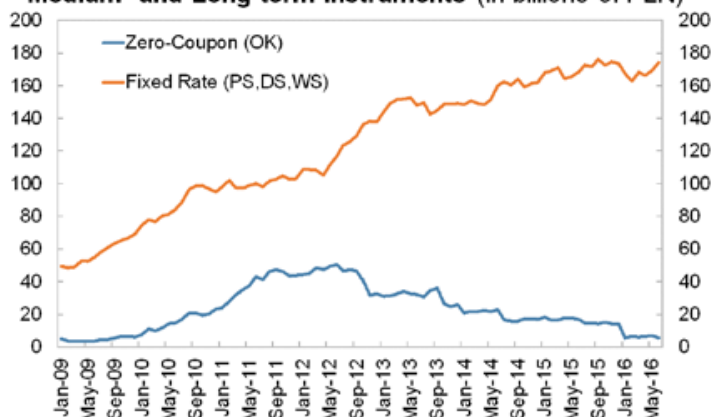
Source: Haver.

Figure 26. Hungary: Treasury Bills' Secondary Market Turnover (In trillions of HUF)

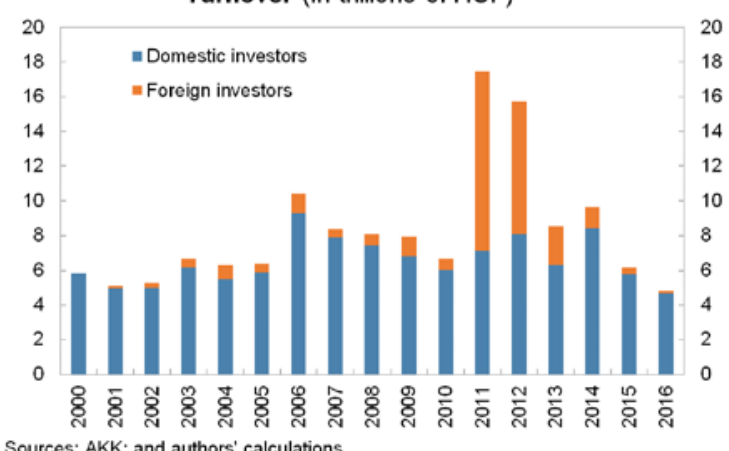
Sources: AKK; and authors' calculations.

Figure 28. Secondary Market Turnover of Domestic Bonds (In billions of MYR)

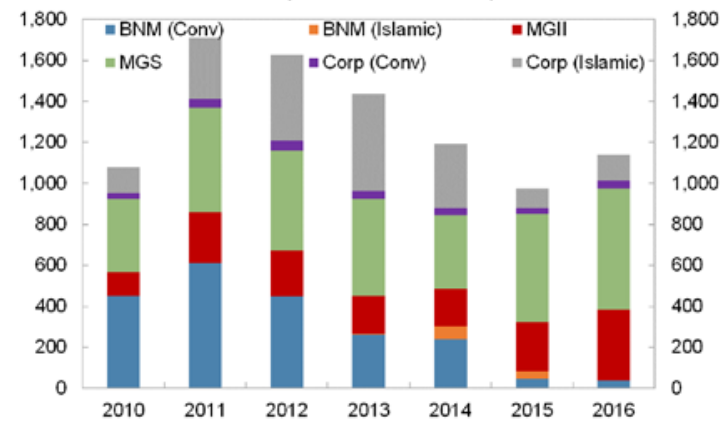

Source: BondlnfoHub

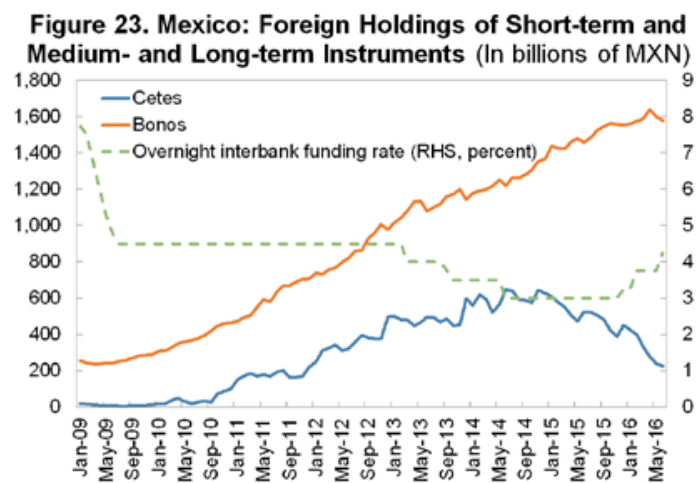

Source: Haver.

Figure 25. Thailand: Foreign Holdings of Short-term and Medium- and Long-term Instruments (In billions of THB)

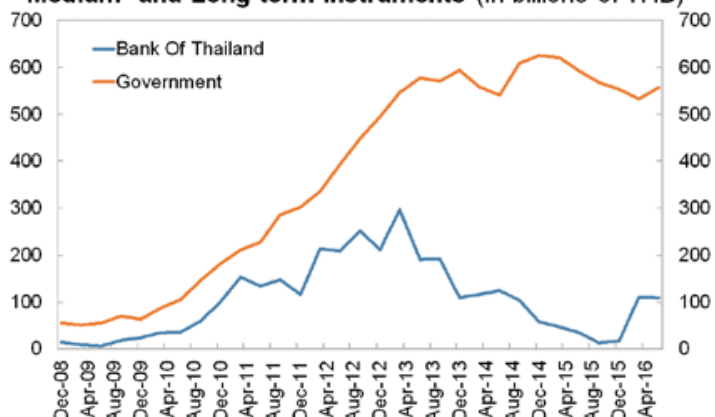

Source: Haver.

Figure 27. Hungary: Government Bonds' Secondary Market Turnover (In trillions of HUF)

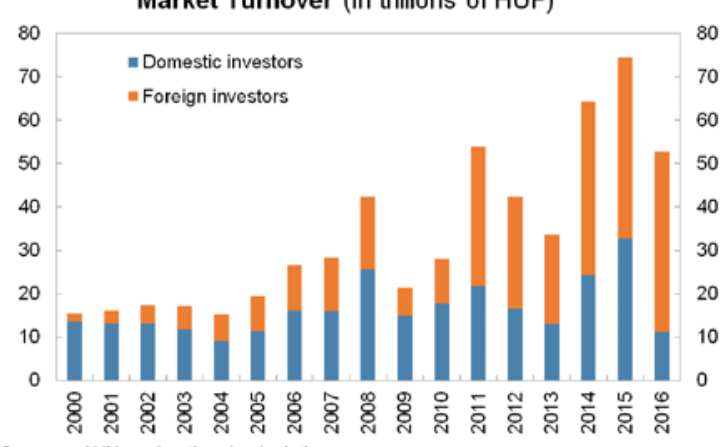
Sources: AKK; and authors' calculations.

Figure 29. Outstanding Amount of Domestic Bonds

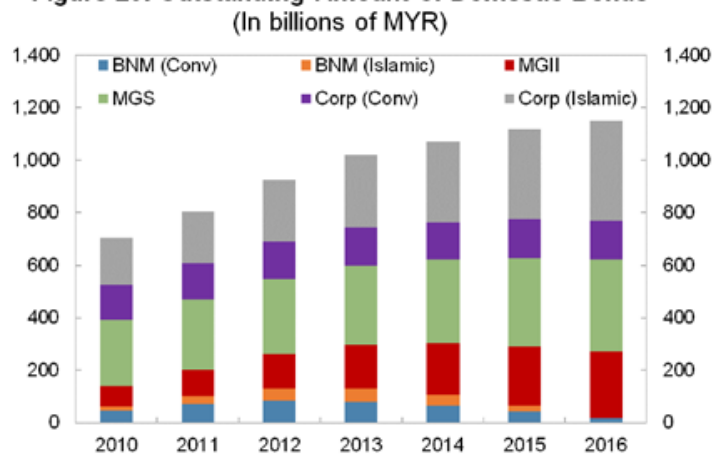

Source: BondlnfoHub. 


\section{Box 1. Bank Data}

To avoid double counting, we process unconsolidated financial statements of each entity which may belong to a particular banking group. Local banking groups in Malaysia generally have three lines of businesses located in different legal entities: commercial banking, Islamic banking, and investment banking. The chart below presents two typical organization forms of the intragroup holdings. Most of the holdings of MGS/MGII and BNM/Treasury bills are booked on the balance sheets of commercial and Islamic banking entities, while the investment banking entities have generally insignificant size in both total assets and holdings of MGS/MGII and BNM/Treasury bills.

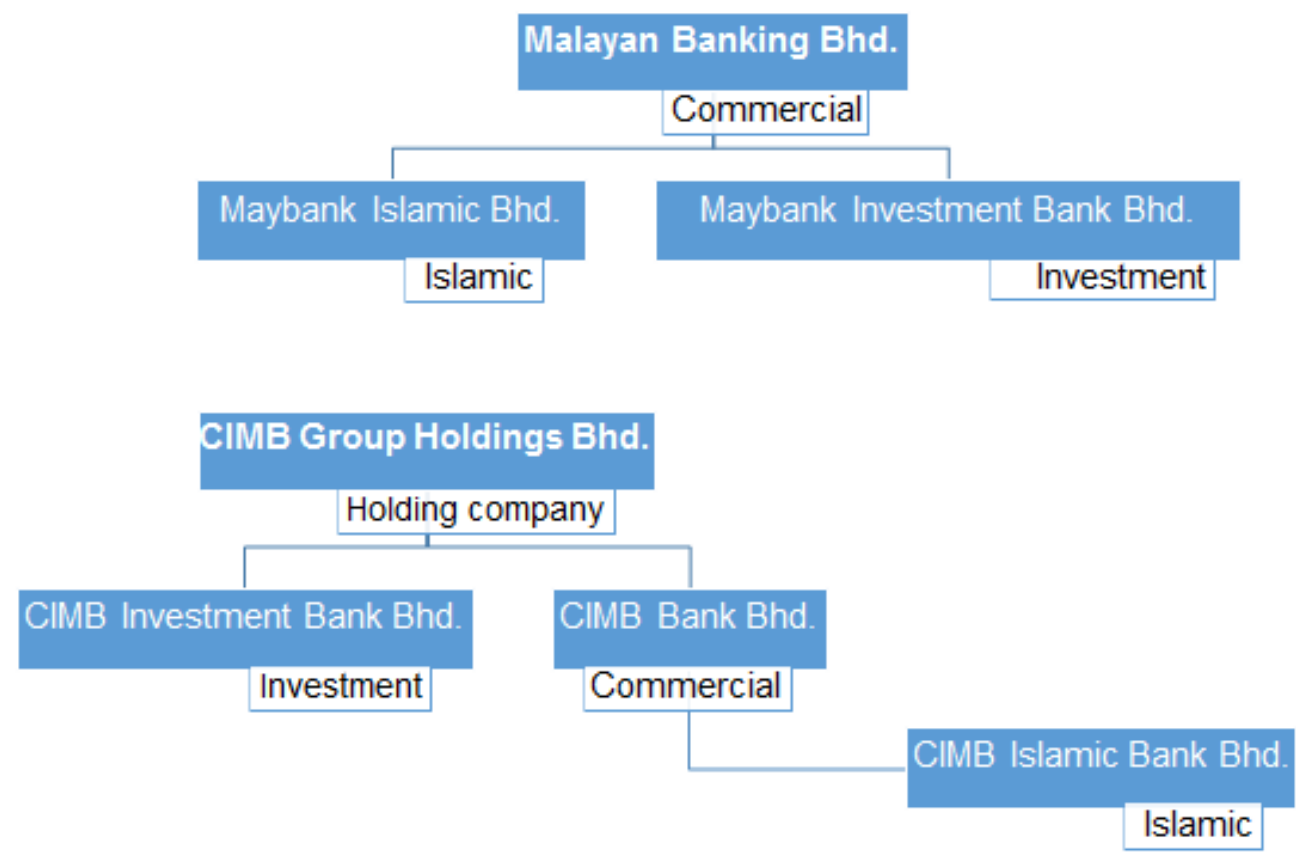

For a given bank, its position in fixed-income instruments can be split into three accounting categories: a) Financial assets at fair value through profit or loss ("FVTPL") which are broadly equivalent to its subcategory - financial assets held for trading ("HFT"); b) financial assets available for sale (“AFS"); and c) financial assets held to maturity ("HTM"). The accounting treatment of HTM is similar in the IFRS and Malaysian FRS, which implies that the positions classified as HTM are ineligible for secondary market trading except in very rare cases. Thus, a bank with large holdings in a given bond will still have little impact on the secondary market pricing and turnover if most of its holdings are classified as HTM. For most of the banks the difference between FVTPL and HFT categories is negligible, so in our text we usually use the name HFT for the whole FVTPL category. 


\section{INVESTMENT STRATEGIES OF THE FOREIGN INVESTMENT FUNDS}

A decomposition of foreign investors in Malaysian domestic bonds can illustrate the importance of asset managers, mainly foreign collective investment vehicles (referred to foreign investment funds, FIFs, in the paper). They were the largest foreign holders of Malaysian domestic bonds in the second quarter of 2017, followed by central banks and governments (likely in the form of reserve assets or assets held by sovereign wealth funds), pension funds, and banks (Figure 30).

The availability of the micro-level data of the FIFs, a result of the mandatory disclosure

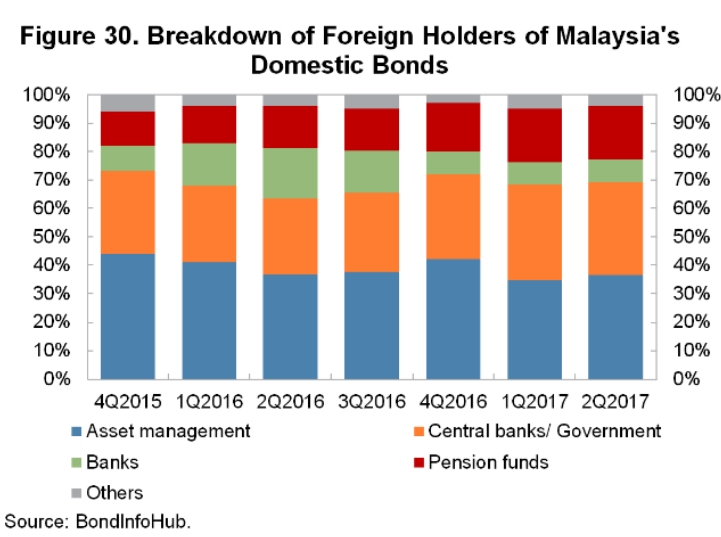
requirement, has enabled us to understand their behavior in the fixed-income and other related markets. Such data could provide insights on their portfolio management decisions that would influence the dynamics in the Malaysian domestic fixed-income market and other markets such as the FX and interest rate (IR) derivatives markets. The focus here is their holdings of MGS, as foreign holdings of MGII and corporate bonds are much smaller. Nevertheless, the popularity of MGII has increased among foreign investors including liquidity-dependent vehicles such as the ETFs (e.g., ABF Pan Asia Bond Index Fund and iShares J.P. Morgan EM Local Govt Bond UCITS ETF).

\section{Foreign investment funds}

The data from Bloomberg Finance L. P. indicate that more than 500 FIFs managed by about 150 foreign asset management groups had positions in MGS in the first quarter of 2017. Approximately 95 percent of the FIF holdings in MGS were managed by funds with fixedincome mandates; while the remaining 5 percent were managed by funds with multi-assets mandates. Approximately one-third of the FIF holdings in MGS had global mandates and the remaining two-thirds EM mandates. Even though many of the FIFs had formally assigned benchmarks for asset allocation, most of them had a total return mandate allowing them to deviate from their benchmarks.

The large number of the FIFs provides the MGS market with a stream of secondary market orders but generally the FIFs are unlikely to engage in high-frequency trading. Most of them have insignificant allocations to MGS: fewer than 10 funds had more than onebillion-ringgit exposure, and about 85 percent had allocations smaller than 100-million-ringgit (Figure 31). Given that the management fee for the institutional shares classes generally range between 0.4 percent and 0.8 percent of the

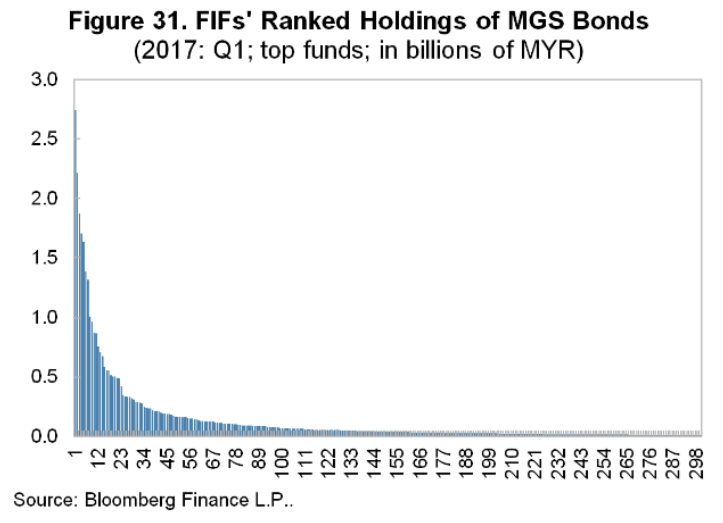


AUM, the small size of revenues pro rata attributed to the MGS positions for most funds does not seem to justify allocating a large operational resource for high frequent trading of MGS.

The top 10 FIF holders of the MYR-denominated bonds as of end-2016 had diverse exposures to the Malaysian FX and interest rate risks (Figure 32). There are funds that almost fully eliminate the FX exposure to the MYR (e.g., Vanguard Total International Bond Index Fund, and T. Rowe Price International Bond Fund) as well as those that have extra exposure to the MYR on top of the cash bonds (e.g., Templeton Global Bond Fund, and PIMCO Emerging Local Bond Fund). On the interest rate risk, there are funds that concentrate their positions to predominantly short-term bonds (e.g., Templeton Global Bond Fund) as well as those that concentrate their positions to long-term bonds (e.g., PIMCO Emerging Local Bond Fund).

Figure 32. FIFs: Top 10 Largest Holders of MYR Bonds (end-2016)
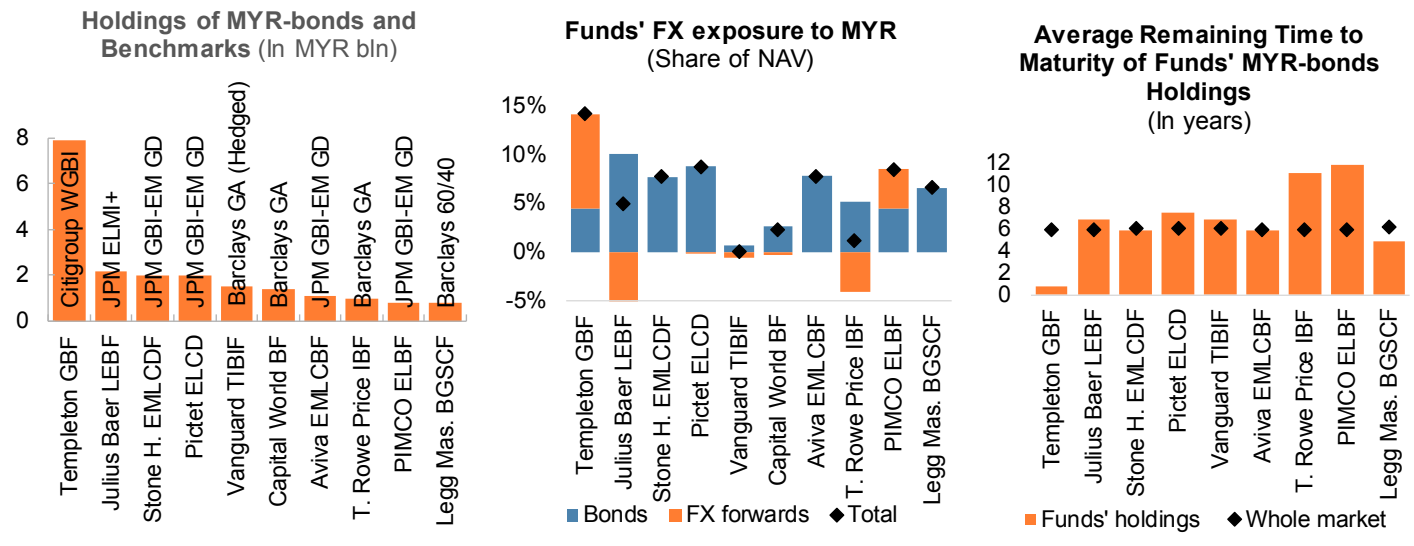

Sources: Funds' reports; and authors' compilation. Note: ETFs are excluded.

Derivatives are often used by the FIFs to actively manage their portfolios, in particular the FX forwards. For example, PIMCO, which actively manages its Emerging Local Bond Fund, has built its exposure to the Malaysian FX and IR risks through not only cash bonds but also FX forwards and interest rate swaps (IRSs) (Figure 33). FX forwards are present in virtually every FIF, while the usage of IRSs is less common - the counterparties for the FX forwards and IRSs are typically global investment banks. The Templeton Global Bond Fund's investment behavior has also demonstrated the crucial role of the FX forwards in its active management of the exposure to Malaysia (Box 2). Despite the

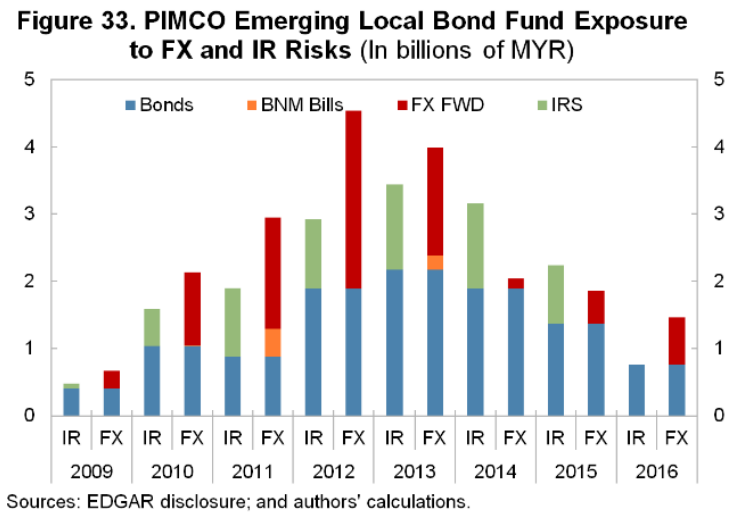
importance of the FX and IR derivatives for active management, they are usually cashless in nature because the portfolio managers of the FIFs prefer netted versions of the derivatives. In 
this regard, cash bonds remain to be the main recipients of the global liquidity while the availability of derivatives would influence the willingness of investors to hold cash bonds. Relatedly, for policy makers, the analysis of the risk related to the foreign ownership of LCY bonds ideally could cover not only foreign holdings of cash bonds but also other instruments such as derivatives.

\section{Key features of MGS}

MGS provide foreign investors with exposure to both the FX and interest rate risks. One key difference between investing in the Eurobonds and LCY bonds issued by the same credit is that the latter carry the currency risk. The MGS coupons represent a low but stable yield stream of income for investors; while the level of the FX volatility in Malaysia is high relative to the bond yield volatility (Figures 34-35). This is because as a small open economy with relatively large financial markets and commodity production, its exchange rate could be heavily influenced by the dynamics of both the global risk appetite and commodity prices. Consequently, most profits and losses (P\&L) of LCY bonds come from FX fluctuations (Figure 36).
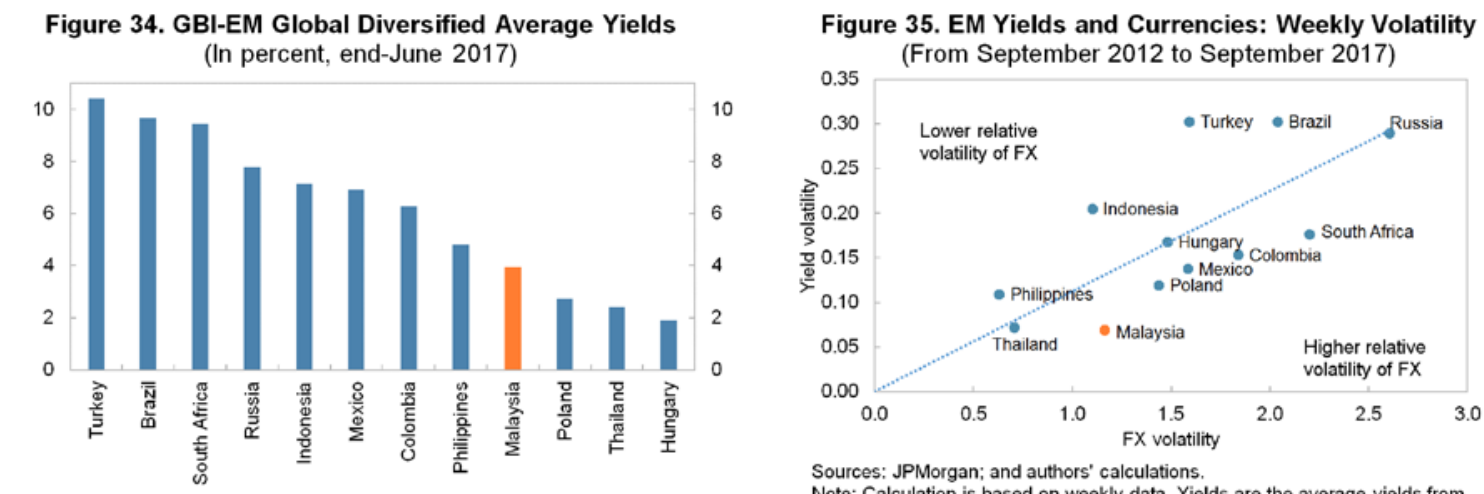

Source: JP Morgan.
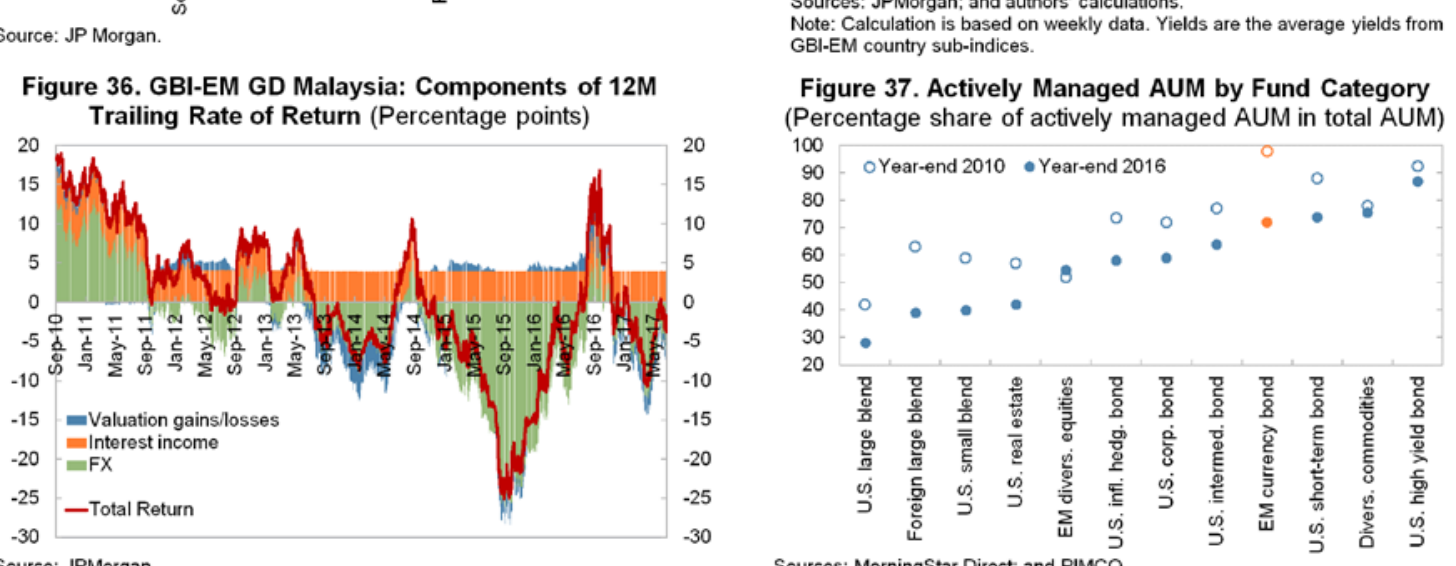
GBI-EM country sub-indices.

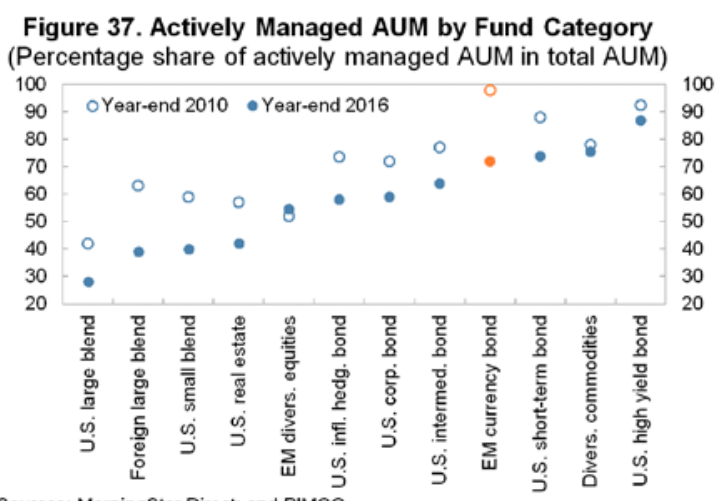

Generally, the EM LCY bonds asset class is perceived as having its share of actively managed funds among the highest across all asset classes (Figure 37). Activism is important in the case of Malaysia as well: with its high level of FX volatility and low yields, active management of the FX exposure could provide a potential source for additional returns compared to the pure management of the IR exposure. The Box 3 demonstrates that the 
spectrum of the FIF active strategies in the EM LCY bond asset class could span from pure bonds positions to pure FX positions with alpha generated by "currency overlay" and/or "portable alpha" structures. Asset managers marketing their FIFs with EM LCY bonds mandate tend to emphasize their ability to generate a positive alpha through relative value trades due to the strength of their in-house macro research (e.g., T. Rowe Price, Pioneer $\underline{\text { Investments, }}$ and Natixis Global Asset Management).

\section{Separating the FX exposure and duration exposure}

The practical implementation of a FIF's active strategies with Malaysian bonds relies on the possibility of separating the FX exposure from the duration exposure (Table 1). The FX exposure refers to investing US dollar liquidity in the Malaysian short-term instruments and receive interest income accrued at the Malaysian short-term yield, therefore having almost zero exposure to the duration but having full exposure to the FX risk (the numéraire of the portfolio is assumed to be the US dollar). The separated duration exposure refers to hedging the FX risk by paying the associated cost of hedge, while receiving the term-spread and being exposed to capital gains and losses arising from the fluctuation in the bond price. The detailed description of the two strategies is presented in the Annex I.

\begin{tabular}{|c|c|}
\hline $\begin{array}{l}\text { Separated FX } \\
\text { exposure }\end{array}$ & $\begin{array}{l}\text { Accrued income: MYR short-term interest rate } \\
\text { Revaluation: USDMYR movements } \\
\text { Risk: FX risk }\end{array}$ \\
\hline \multirow{2}{*}{$\begin{array}{l}\text { Separated } \\
\text { duration } \\
\text { exposure }\end{array}$} & $\begin{array}{l}\text { Accrued income: USD short-term interest rate + } \\
\text { MYR term spread }\end{array}$ \\
\hline & $\begin{array}{l}\text { Revaluation: bonds' capital gains\&losses } \\
\text { Risk: interest rate risk }\end{array}$ \\
\hline
\end{tabular}

\section{FX exposure}

There are two main ways to obtain an FX exposure. The first is to convert the US dollar liquidity into the MYR in the FX spot market and invest the MYR-denominated proceedings in short-term instruments, such as the BNM bills, treasury bills, or short-term government bonds.

The second approach is to construct a synthetic exposure by investing the US dollar liquidity into a USD-denominated short-term instrument and engaging in a cashless NDF transaction (i.e., a forward purchase of MYR), a popular strategy in particular prior to the reinforcement of the existing rules on domestic institutions' participation in offshore ringgit transactions (IMF, 2017). This synthetic position is equivalent to investing in a short-term MYRdenominated instrument which generates interest income at the yield equal to the implied yield of the NDF contract.

Operationally the second approach could be more efficient than the first one, as the markets for both US dollar-denominated short-term instruments and NDFs are much more liquid than the market for Malaysian domestic instruments (Figure 38). The improved efficiency comes up with a price, as the interest rate in the synthetic positions is generally lower than the yield of the domestic bills and bonds (Figure 39).

The Templeton Global Bond Fund presents a case of combining these two approaches to obtaining the FX exposure (Box 2). It shows that the total exposure to the MYR risk was 
long and had been stable as a share of the net asset value (NAV) in 2013-16, however, the composition of the instruments that generated the exposure varied from year to year.
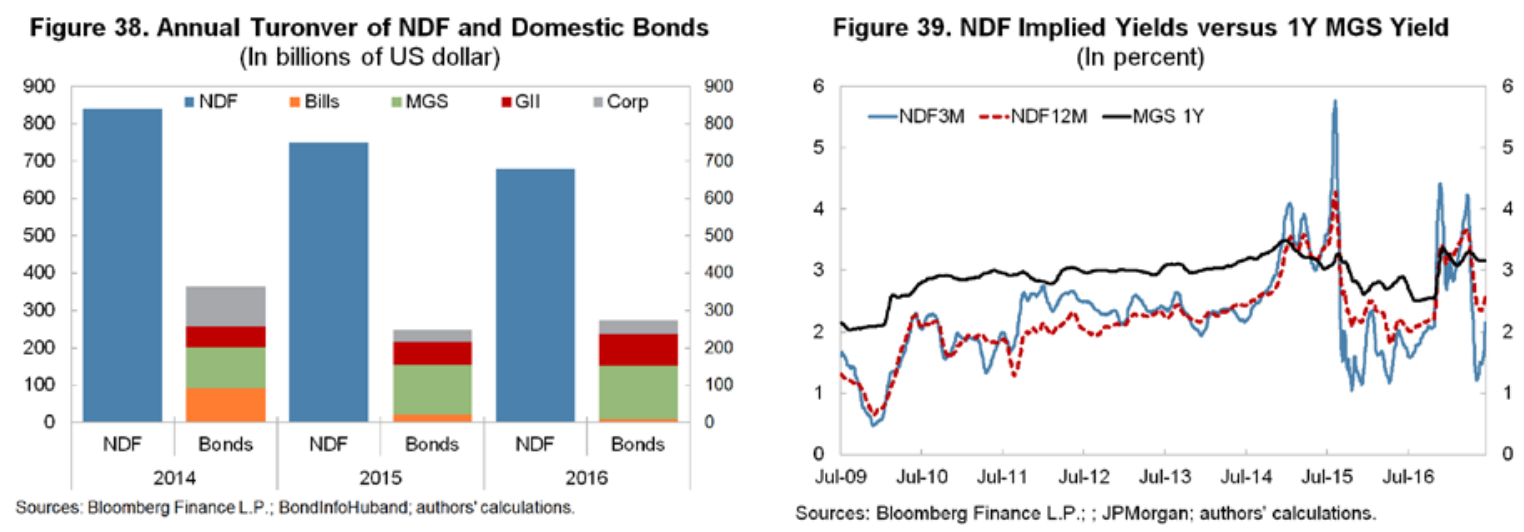

The remuneration for bearing the FX risk is usually smaller in Malaysia than in other EM countries. This can be observed from the return of the systemic rolling-over unfunded shortterm FX positions adjusted for risk (i.e., FX volatility) (Figure 40). Some high-yielding currencies offer higher remuneration for bearing FX risk (e.g., Brazil BRL and Turkey TRY) and some mid- to lower-yielders have lower FX volatility (e.g., Peru PEN and Philippines PHP), while the MYR offers neither high yield nor low FX volatility. Therefore, a strong bullish view on the Malaysia fundamentals is often a reason for an

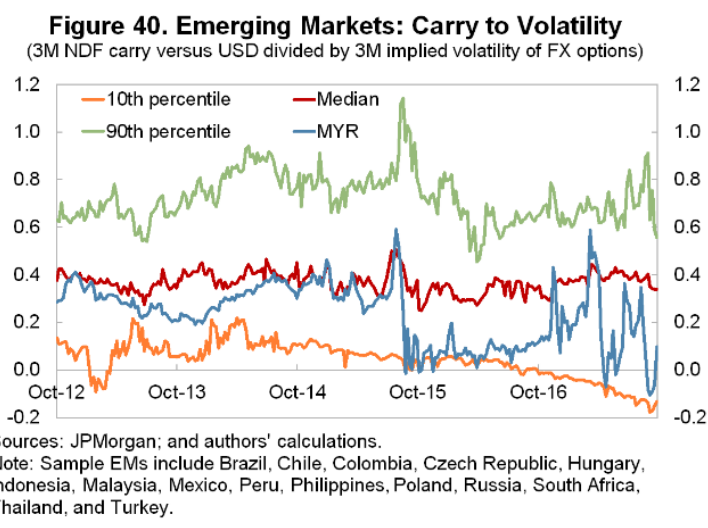
investor to build the short-term MYR position.

\section{Separated duration exposure}

The separated duration exposure refers to the fully FX-hedged purchase of Malaysian bonds. Eliminating FX risk requires the forward sale of MYR, which is equivalent to paying the short-term FX forward implied yield as the cost of hedge. Therefore, the FX-hedged purchase of Malaysian bonds could generate interest income but also involve interest expense as the cost of hedge. In other words, the hedged position yields the US short-term interest rate, Malaysian term spread, and the capital gains and losses of holding Malaysian domestic bond. The detailed implementation is described in the Annex I.

The attractiveness of the systematically hedged FX exposure is very limited in the case of Malaysia. As presented in the Annex I, the FX-hedged P\&L can be rewritten as

Hedged Malaysian bonds' $P \& L$

$=[P \& L$ from US Treasuries] + [Risk Add-On], 
where Risk add-on captures the relative impact of the idiosyncratic developments in the US and Malaysia domestic bonds markets. This is the spread between the return of a fully FXhedged position in MGS and the return of a position in the US treasuries. The spread is small compared to those of the hedged positions of some other EM bonds, which are comparable to the spread of the unhedged position of MGS (Figure 41). Overall, ranked by the size of the spread, the fully-hedged Malaysian bond return is closer to the returns of the developed market bonds rather than to the returns of EM bonds (Figure 42).
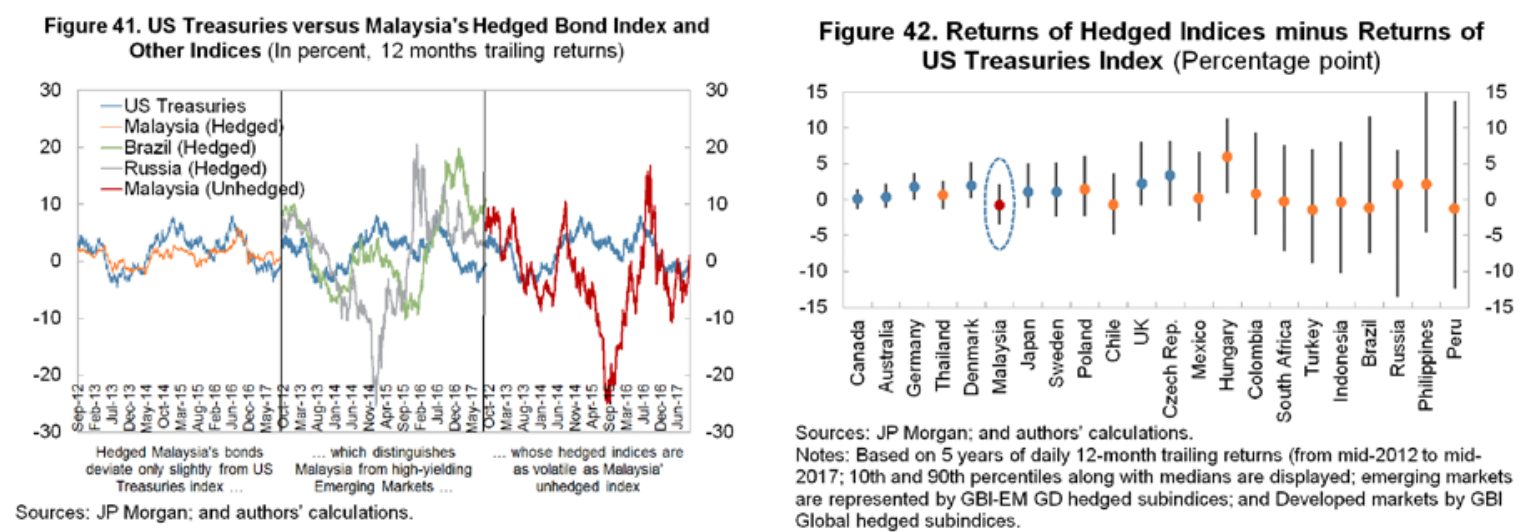

An example of a fund systematically eliminating the FX exposure is the Vanguard Total International Bond Index Fund. It invests in local bonds of worldwide developed economies and EMs. The fund fully hedges its investments in local bonds as required by its mandate to benchmark to Bloomberg Barclays Global Aggregate ex-USD-USD hedged. However, this one is probably the only fully-hedged fund with a significant position in Malaysian bonds (Figure 32). Remaining funds with full-hedge mandate represent in total less than 2 percent of the FIF holdings in MYR-denominated bonds.

Even though the systemic and persistent elimination of the full FX exposure makes the investments in Malaysian local bonds relatively unattractive compared to other EMs, there are still viable cases for partial and temporary reduction in exposure to the MYR. In particular, active management of the split between the pure FX and pure duration exposures allows for the implementation of strategies that react to the relative value attractiveness of the MYR and duration. The availability of hedging instruments is important for investors to conduct the split. Such availability is more significant during stress, as they provide an option for investors to close the FX exposure. Should investors lose their confidence in the access to hedging instruments, they would have to apply stricter requirements on bonds liquidity which will substantially narrow the set of acceptable bonds.

While most of the FIFs are actively managing their EM LCY bonds exposure, the passive vehicles such as ETFs are gaining popularity. Even though some ETFs actively manage their portfolios (e.g., WisdomTree Emerging Market Local Debt Fund), most of them are passively following a respective index. Based on the data from Bloomberg Finance L. P., the ETFs represent about one-tenth of the FIF holdings in MYR-denominated bonds. 


\section{Box 2. Templeton GBF's Exposure to MYR Bonds and FX Forwards}

The investment behavior of the Templeton Global Bond Fund (GBF) can indicate the roles of cash bonds and FX derivatives in portfolio management. The Templeton GBF has a global fixed-income mandate. Its NAV ranged from US\$40bn to US\$70bn from 2010 to 2016 (Chart 1). It has total return basis, meaning that it does not have to strictly follow any bond benchmark weights. For example, even though GBF has Citigroup WGBI as its benchmark, it heavily invests in EMs.

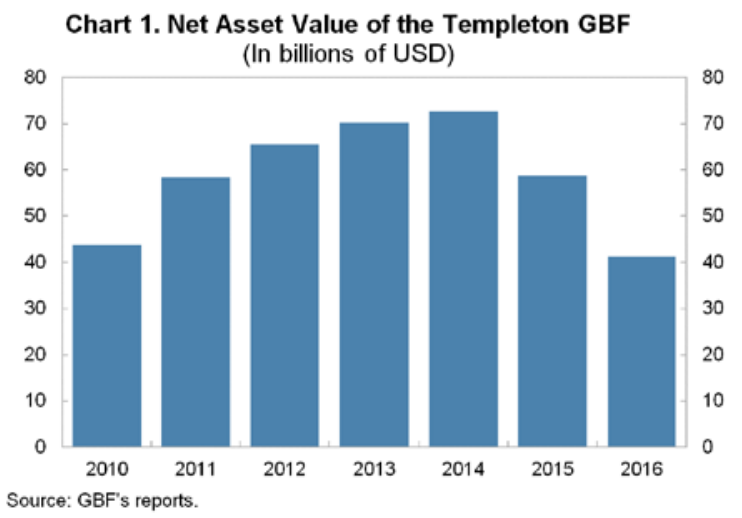

The fund's position in MGS was large and volatile. At end-2016, its position exceeded those of most domestic banking groups (Chart 2), and historically, its position in MGS even exceeded that of the largest domestic banking group, Maybank (Chart 3). Its bond holdings were also volatile: they could decline from MYR16bn to less than MYR4bn in one year (e.g., from 2013 to 2014). In spite of having a large position in MGS at end-2016, it sold all of them by end-March 2017 and closed all the remaining NDF contracts on the MYR by end-June 2017, as it considered Malaysia too externally dependent (Templeton, 2017).

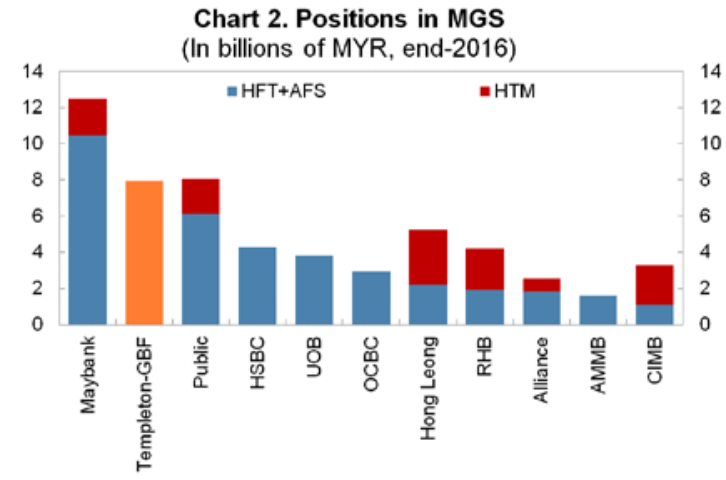

Sources: Banks' annual reports: and authors' calculations.

Despite the volatile holdings in MGS, GBF's total exposure to the MYR as a share of the NAV was relatively stable at around $13 \pm 1$ percent over $2013-16$. A large chunk of the exposure to the MYR was obtained through FX forwards (Chart 4). For example, in 2016, they accounted for about 70 percent of the total exposure to the MYR. In 2014, short-term bills were the main instruments for the GBF to gain exposure to the MYR.
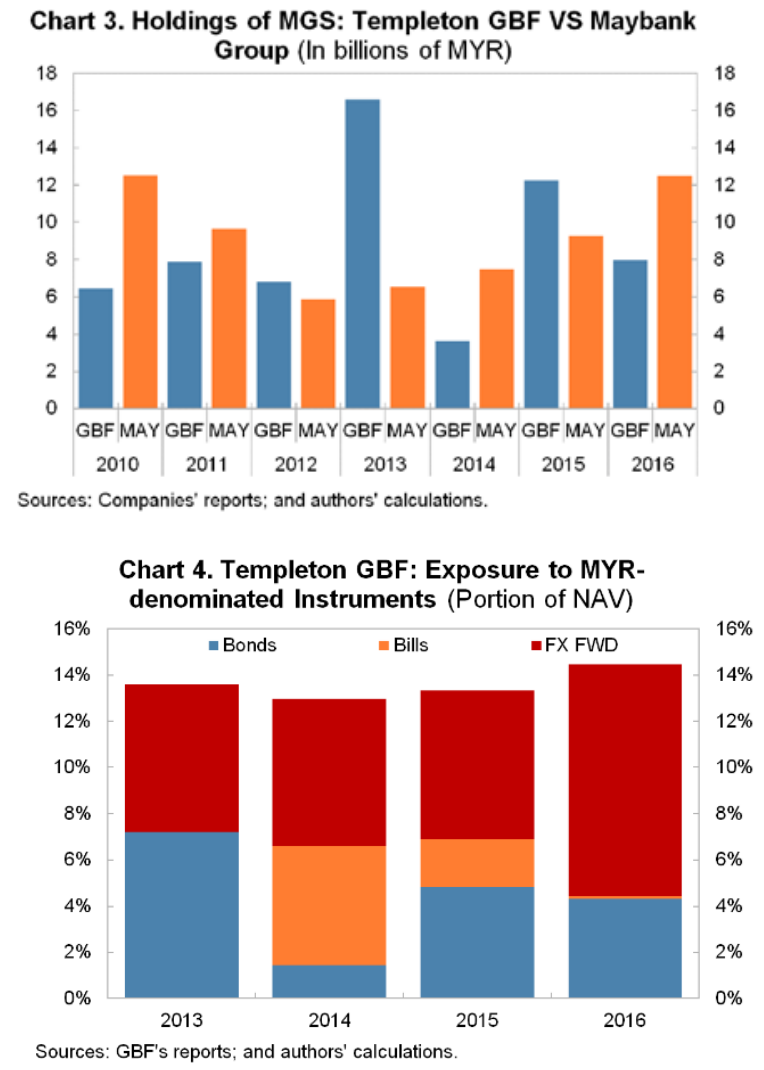


\section{Box 3. Spectrum of Investment Strategies: Currency Overlay and Yield Enhancement}

The FIFs often use both the bond positions (benchmarked by GBI-EM) and FX positions (benchmarked by ELMI+) to manage their exposure to EM LCY bonds. Passive allocations to either 100 percent GBI-EM or 100 percent ELMI $+{ }^{1}$ produce similar returns because both are driven mostly by the FX performance and both include interest income component accrued at a short-term rate (for bonds) or the implied yield (for FX forwards) (Charts 1-2). The deviation of returns of the GBI-EM compared to the ELML+ is explained by the accrued term spread attributed to the valuation gains and losses of longer-dated bonds.
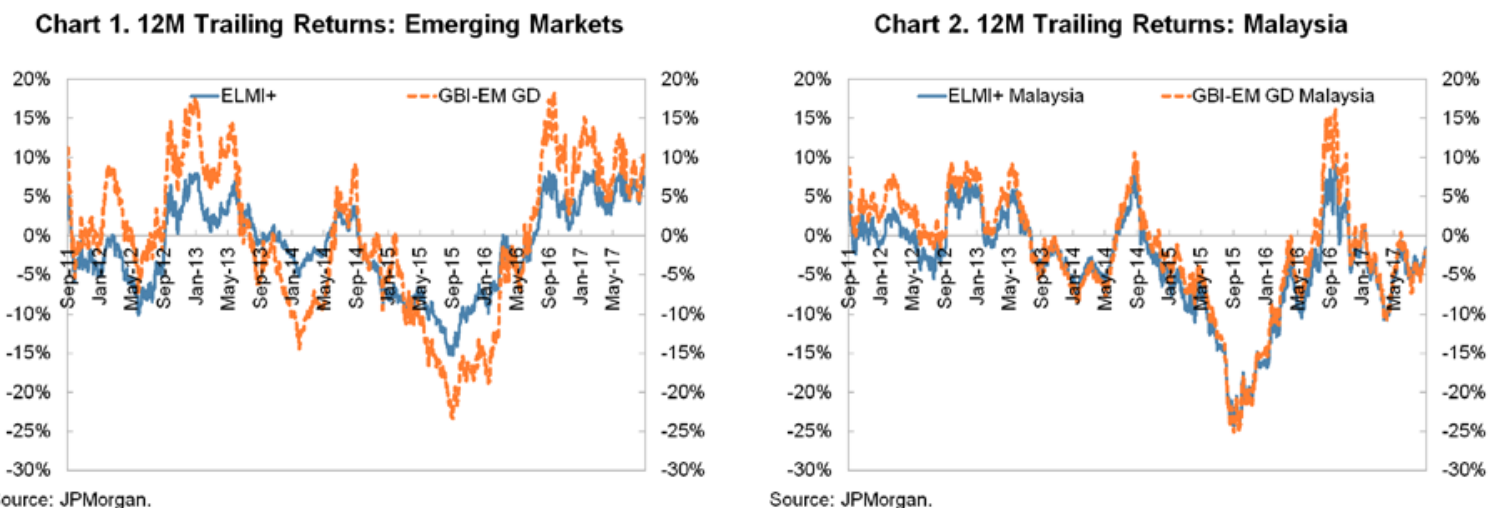

Depending on their expertise and willingness to engage in the active management of the FX positions, the portfolio managers of the FIFs may choose to put more emphasis on either bond positions or FX strategies. In particular, they may consider bond holdings as the core position that generates interest income and provides the base level of the FX and IR risks, while the active FX management provides portable alpha from the currency overlay strategies. Or they may engage mostly in active FX trading and consider investments in bonds as a way to increase the interest income on top of the FX positions. Chart 3 summarizes the spectrum of the strategies between pure bonds and pure FX positions. In addition, an FIF may locate different countries to different parts of the spectrum and these locations may vary through time depending on the judgements of portfolio managers.

Chart 3. Spectrum of Investment Strategies
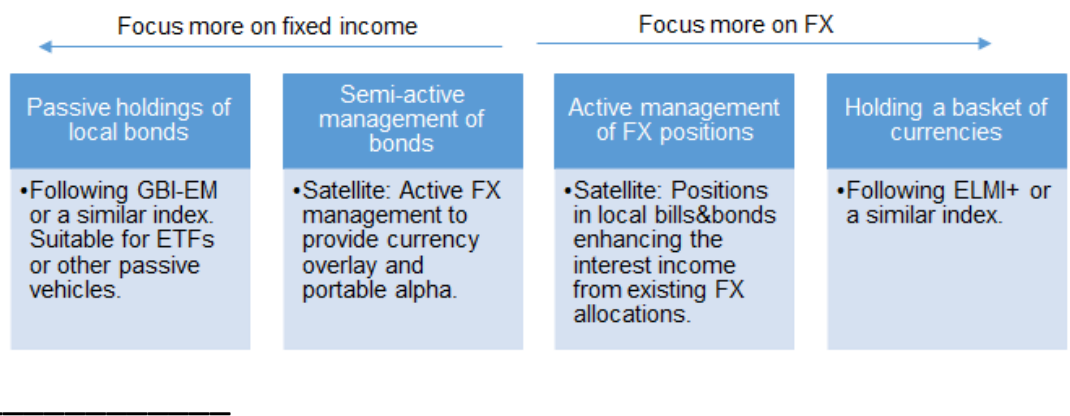

${ }^{1}$ J.P. Morgan Emerging Local Markets Index Plus (ELMI+) tracks total returns for local-currency denominated money market instruments in emerging market countries. It is constructed as a strategy of rolling over shortterm FX forwards (deliverable and non-deliverable). 


\section{FaCtors Influencing The MALAYSIA Weight In GBI-EM INDICES}

Foreign asset allocation to Malaysia may be driven by Malaysia's fundamentals, by global risk appetite, or by individual portfolio managers' judgements. However, given the high share of the GBI-EM-AUM implied foreign allocation in Malaysian credit (Figure 43), the impact of the change of Malaysia's weights in the GBI-EM indices may be important as well.

It's not uncommon that a country's weight in one of the GBI-EM indices is sharply cut in a relatively short period of time (e.g., 6-12 months). Such a reduction is usually a consequence of a decline in the market value of the country's bonds in the US dollar terms during a market turmoil. The decline typically could be decomposed into two: the devaluation of the country's currency against the US dollar and the decline in the domestic bond prices as a result of a yield spike. These two factors can for example explain almost all the declines in the weights of Indonesia and Russia during some shock episodes (Figure 44). Such shock-driven declines in weights usually do not require an index-follower to reduce the corresponding position, as the LCY denominated notional value of the index-driven stock of domestic bonds generally does not change.

Malaysia has experienced a significant decline in its weights starting from early 2016. For example, its weight in the GBI-EM GD declined from 10 percent on February 26, 2016 to 6 percent on August 31, 2017 (Figure 45). Compared to the changes in the exchange rate and bond price, other factors have played larger roles in contributing to the overall weight cut (Figure 46):

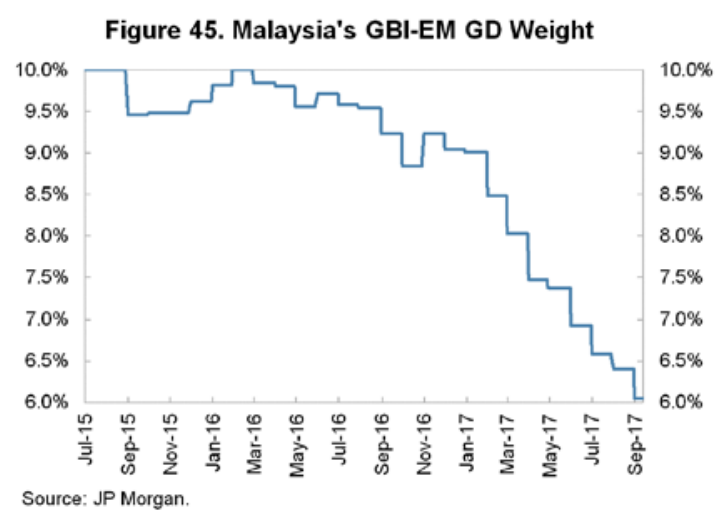


- New constituents (-0.47 percent). It reflects the reduction of weight due to the inclusion of Argentina and the Czech Republic to the index.

- Illiquid bonds (-1.12 percent). Bonds assessed as illiquid by J. P. Morgan are removed from the GBI-EM indices. The frequency and the magnitude of the exclusion for Malaysia have intensified since early 2016, which has significantly reduced the notional amount of the Malaysian bonds eligible for the GBI-EM indices (Figures 47 and 48). J. P. Morgan has attributed the ongoing downgrade in the liquidity status of individual MGS to the developments in the NDF markets, and

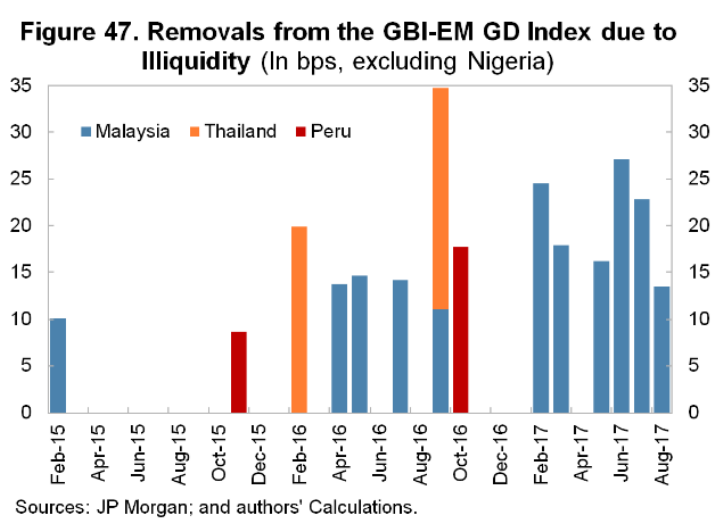
stated that it would continue to assess the liquidity of the MGS and MGII included in the GBI-EM indices. ${ }^{5}$ The secondary market turnover in the first half of 2017 indicates that additional bonds may be excluded (Figure 49).
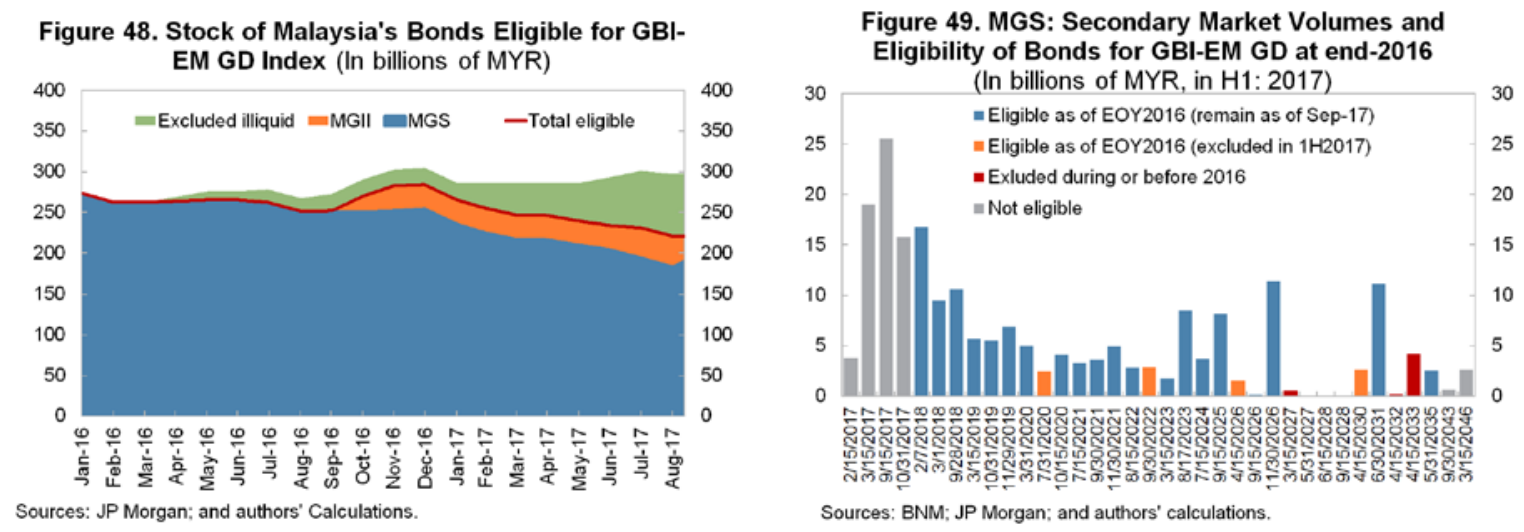

- Inclusion of MGII (+0.74 percent). Since end-October 2016, sukuks has become eligible for the GBI-EM indices. The existing stock is assessed case-by-case for inclusion in the indices, while the new issues are included should they pass the index criteria such as the size of the bond (J.P. Morgan, 2016). The inclusion of MGII has partially compensated for the exclusion of the illiquid MGS. If judged solely by the secondary market turnover, potentially 3-4 more MGII could be included in the indices. However, the total notional

\footnotetext{
5 "Changes in the NDF have impacted MGS liquidity resulting in reduced weight over the past six months" (J.P. Morgan, 2017a). "Malaysia remains eligible for the GBI-EM and ELMI+ indices. Nonetheless, we will continue to closely assess the liquidity of the MGS and MGIIs included in the GBI-EM indices to ensure investors' ability to replicate the index allocation" (J.P. Morgan, 2017b).
} 
amount of the included MGII is smaller than the set of the excluded illiquid MGS. In addition, the recently-included MGII could also be subject to exclusion. For example, the bond "MGII 3.7430\% Aug-2021" (included in November 2016) was excluded in August 2017 due to illiquidity (Figure 50). Nevertheless, the inclusion of MGII in the GBI-EM indices reflects the successful development of this market segment by the authorities. The net issuance of MGII was close to that of MGS

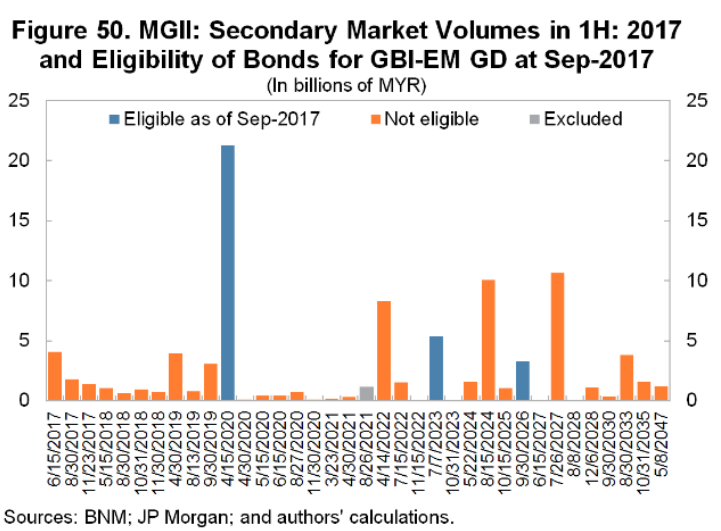
in 2016 and overpassed that of MGS in several years, resulting in an increase in the share of MGII in the total stock (Figures 51-52).

Figure 51. Annual Net Issuance of MGS and MGII

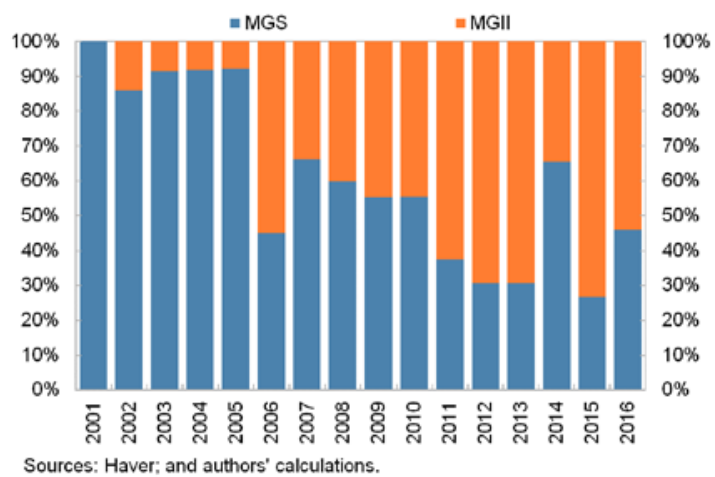

- Relative supply (-2.27 percent). The most important factor explaining the decline in the Malaysia's weight is the slow pace of the growth of the stock of the GBI-EMeligible Malaysian bonds compared to other GBI-EM GD constituents. Since 2016, even adding back the excluded bonds due to illiquidity, the expansion of the stock of the eligible bonds would be lagging the median of the expansion of other GBI-EM GD constituents (Figure 53).
Figure 52. Stock of Outstanding MGS and MGII Bonds

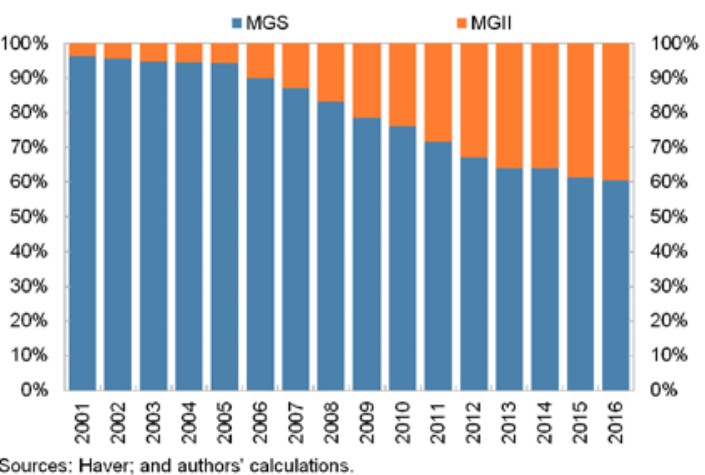

Figure 53. Stock of GBI-EM GD Eligible Bonds (December 2015=1)

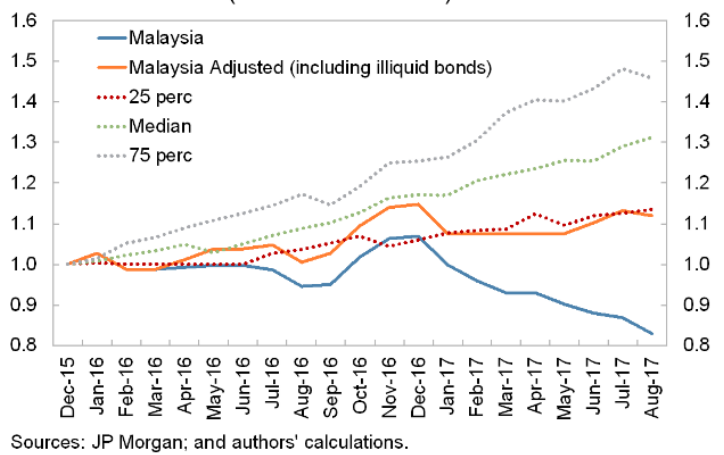

The impact of the cut in weight on foreign demand is difficult to tell though a large-scale change could lead to substantial adjustment. Even though the GBI-EM indices are the most widely used for the EM LCY bonds asset class, most of the benchmarked funds have great degree of active management and are allowed considerable deviations from the precise index weighting (Shek, Shim, and Shin, 2015). For example, a modest decline in the weight of Malaysia would cause very little activity in a mutual fund should the fund's portfolio manager have already kept Malaysia underweight. However, since the fund's performance is 
often evaluated against the benchmark, any large deviation from the GBI-EM weights (in any direction) could contribute to the underperformance against the index should the portfolio manager's bet prove to be wrong. Consequently, a large-scale change in the GBI-EM weights would probably produce substantial adjustments even in the most actively managed portfolios.

\section{The MGS Market Sell-OFF}

Severe episodes of non-resident sell-offs of MGS are sometimes driven by factors that are beyond the control of the foreign portfolio managers. Factors could cover the changes in the benchmark weights, large scales of global risk aversion (e.g., the 2008-09 global financial crisis, and the 2013 taper tantrum), and the reinforcement of the existing rules on domestic institutions' participation in offshore ringgit transactions (IMF, 2017).

During the sell-offs, investors could choose either to implement FX hedging or to sell the underlying bonds to control the risk. Often the cost of implementing FX hedging during a market shock is high, and sometimes selling the underlying bonds instead of hedging FX exposure costs less (Figure 54). If such a bond sale is impossible to execute during a reasonable time frame, investors would probably lose less by closing the FX exposure via an FX forward and then gradually selling bonds, as the previous episodes of shocks indicate that the FX component of the total loss of a position in bonds was no less than the valuation losses from the fall in the bond prices (Figure 55). Consequently, investors' behavior could affect the key financial markets such as fixed-income, FX, and derivatives markets.
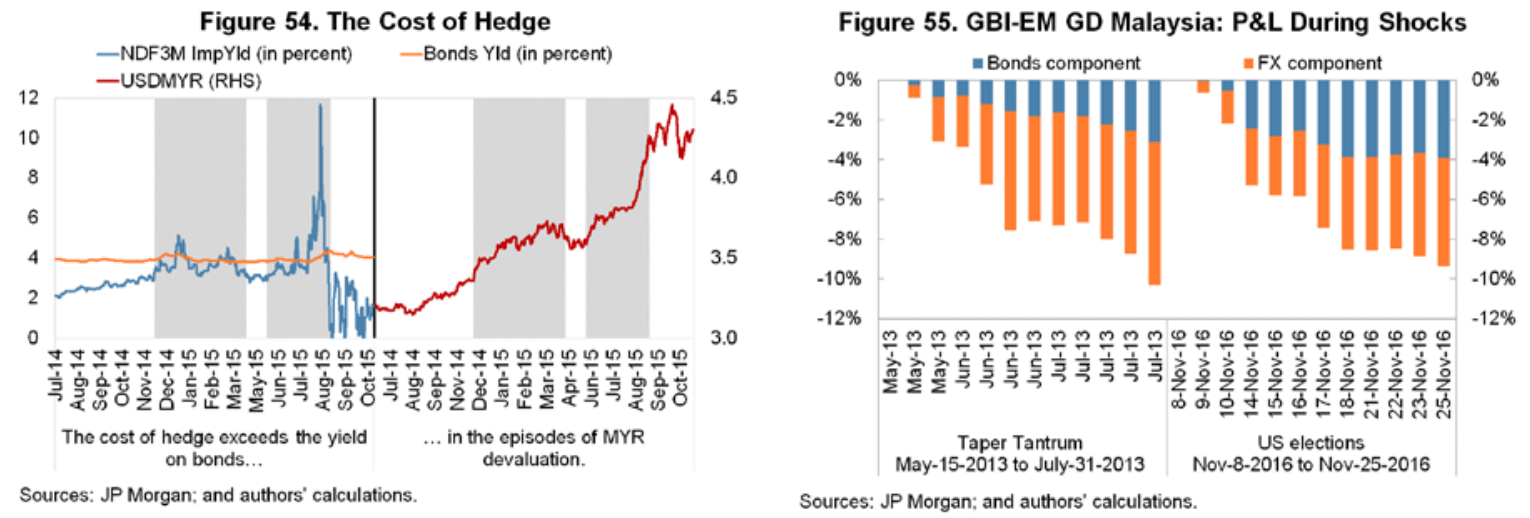

During the shock episodes, the requirements on a counterparty become more stringent. First, the buyer should be able to provide a large pool of liquidity immediately within one to three days if not a few hours. Second, the buyer should be able to tolerate further discount to fair valuation if the erosion to the bond price continues. Third, ideally the buyer should have a time horizon long enough to wait for a rebound. Fourth, as the FX risk is usually the most significant type of risks for a foreign investor during a shock (Figure 55), the buyer may be the one that does not bear the FX risk (e.g., local players) or that can efficiently hedge the FX risk. 
Institutional investors - both local and global ones - generally may not be able to serve as the main counterparty during the sharp sell-offs. They typically cannot provide a sizable pool of external on-call liquidity, as the schedule of their cash inflows is beyond their control. Unlike banks, they are not able to promptly borrow enough liquidity in a collateralized (e.g., REPO) or uncollateralized (e.g., interbank market) form. The ability to raise funds through the sale of other assets during the most severe period of the MGS sell-offs may also be limited as it may legally contradict the institutions' duties to act in the best interest of their clients unless such a switch to MGS is made when holding MGS becomes profitable.

All in all, the expected large buyer during a sell-off would be domestic banks - either a local bank or a foreign bank with significant presence in Malaysia. Besides running down excess reserves placed at BNM, local banks are able to acquire sizable liquidity through REPO and the interbank market. They do not bear FX risk. They may classify new purchases of MGS as HTM to insulate their balance sheets from the mark-to-market P\&L - an accounting option employed during the global financial crisis (Figure 56). Regarding foreign banks, most of the global and regional banks already have subsidiaries domiciled in Malaysia with similar access to the MYR-denominated liquidity as local banks and they maintain sufficient in-

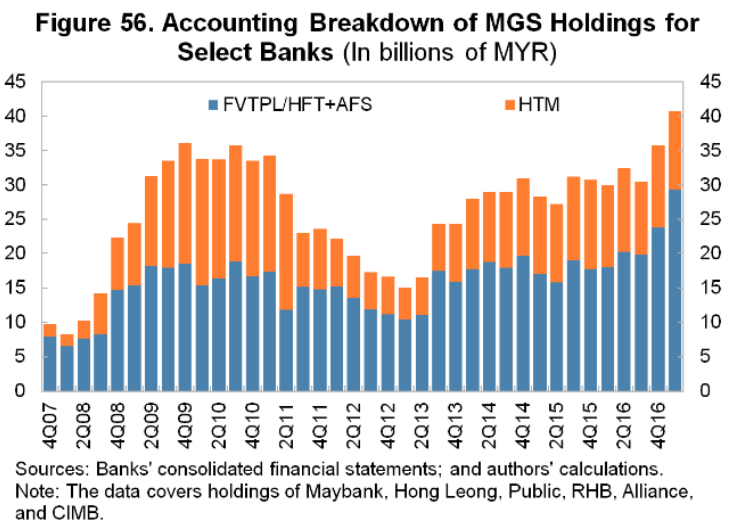
house expertise to form their outlook on the Malaysia risk. As expected, local banks as well as the subsidiaries of foreign banks were the main buyers during the sell-offs of MGS by non-residents (Figures 57-58). The role of institutional investors, including the Employee Provident Fund (EPF), is rather limited after the data consistency adjustment is made (Box 4).

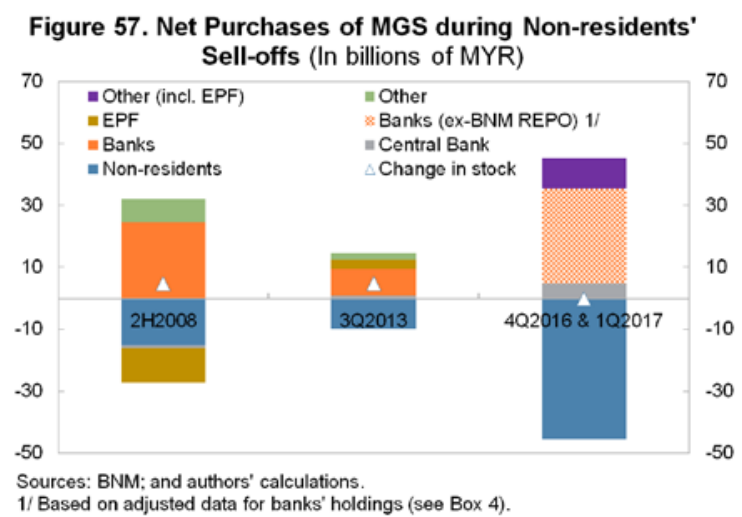

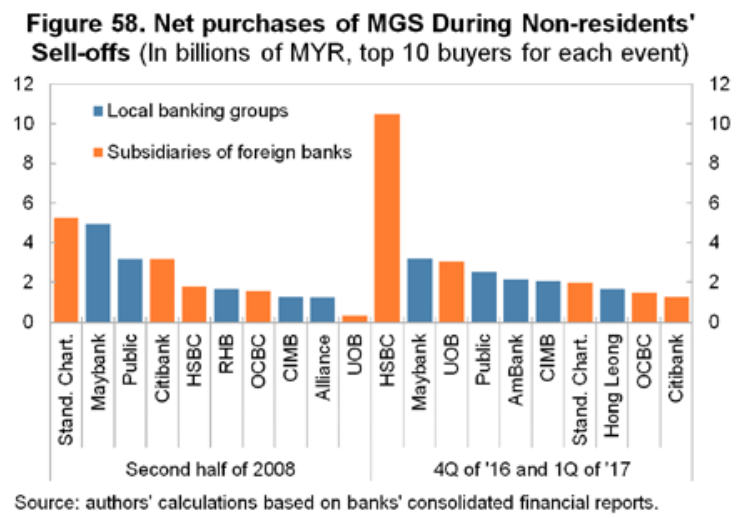




\section{Box 4. Adjustment to the New Format of Presenting the Breakdown of MGS Holders}

BNM changed the format of presenting the breakdown of the MGS holders in 2013-14. The presentation under the old format is closely linked to the legal ownership of bonds and the reported numbers matched closely to the balance sheet values from owners' financial reports. The new format differs from the old one in the attribution of bonds being lent: the old format generally attributes them to the lender, while the new format frequently attributes them to the borrower.

The reported holdings of the EPF and banking institutions are most affected by the change in the reporting format. Since the EPF lends MGS to other parties (for instance BNM), this change would reduce the MGS holdings attributed to the EPF by the amount that it lends out. As we can see, the EPF's holdings compiled by BNM under the old format match the book value in its annual reports; while the new format suggests substantially reduced holdings (Chart 1).

In contrast, for banks the new format would inflate the on-balance sheet holdings by the amount of the off-balance sheet holdings as collateral. It turns out that the amount of BNM REPO that sterilizes banks' excess liquidity is a good proxy for the difference under the two formats (Chart 2). Since BNM has been using MGS borrowed from the EPF for its REPO operations with banks, a reduction in the amount of BNM REPO may cause a release of collateral, increasing the reported numbers of the EPF holdings and reducing the reported

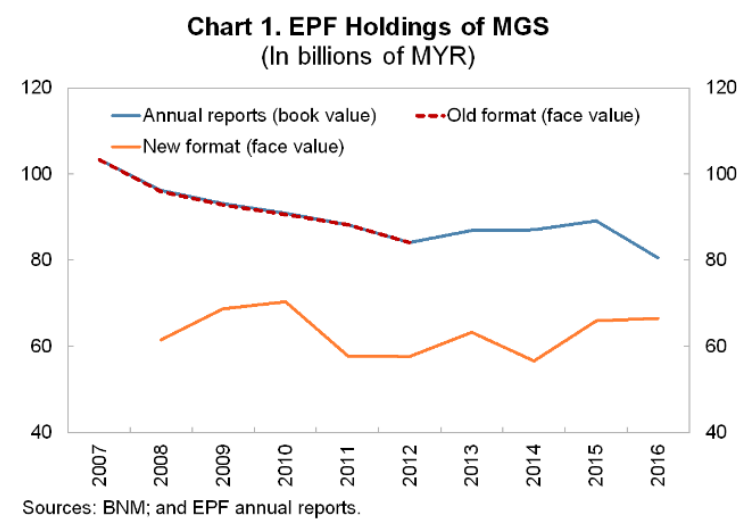

Chart 2. Banks' Holdings of MGS (In billions of MYR)

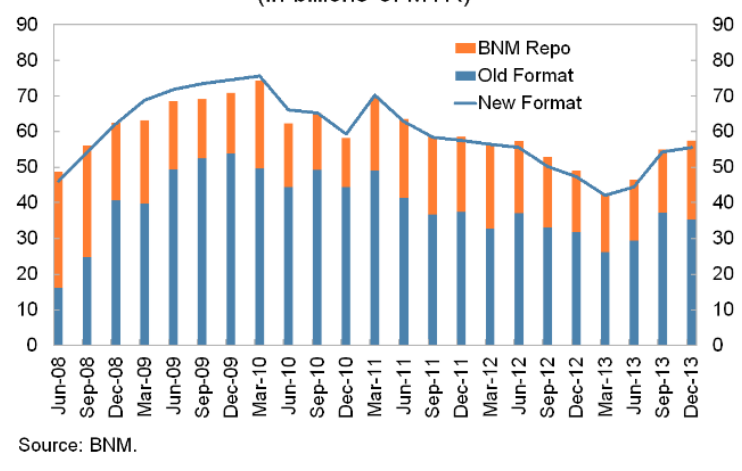
numbers for the bank holdings under the new format, despite no actual change in the ownership. In the section V, we adopt the old format for the holdings of MGS, i.e., we adjust the data published under the new format by deducting the amount of BNM REPO for banks and adding back the amount of BNM REPO for the EPF.

\section{Conclusion}

The impact of the ample global liquidity due to systemic economies' unconventional monetary policies has been felt in the EM LCY government bonds and Malaysia is not an exception. At some point, the share of foreign ownership of MGS reached above 50 percent (in mid-2016). The subsidiaries of the global investment banks have helped to channel the global liquidity into Malaysia given their importance in the secondary market. In addition, they have helped to absorb the foreign sell-offs of MGS during market turmoil. 
The availability of a set of fixed-income instruments that complete a yield curve can help to meet the demand from different types of foreign investors. BNM bills-issued mainly for managing money market liquidity - can help the fixed-income market to absorb the shortterm speculative capital inflows attracted by the perspective of the MYR appreciation and to some extent can help to insulate the MGS and MGII markets from such inflows despite that the BNM bill market may have encouraged more short-term flows in the past (as BNM bill issuance has been discontinued). The efforts by the authorities to promote Islamic bonds have increased the foreign ownership of MGII and led to the inclusion of MGII in the GBI-EM indices, which has helped to compensate for the illiquidity-driven exclusion of some MGS to the indices.

As MGS have low and stable yield but considerable FX volatility, the attractiveness of MGS for many foreign investment funds is not only the level of yields, but also investors' ability to take a position on the direction of the MYR movement and to efficiently use the FX derivatives to add or partially hedge the FX risk. Hence, despite that the FX derivatives themselves do not channel global liquidity, the existence of an effective and efficient FX derivatives market is important, as it could attract different types of foreign investors and help maintain market liquidity and enhance the resilience of the market to global sentiment. At the same time, for policy makers in general, the analysis of the risk related to the foreign ownership of LCY bonds ideally could cover these derivatives as well. In addition, policy measures to improve the functioning of the FX markets could help to attract foreign investors to invest in LCY bonds and enrich the domestic bond market.

The presence of a large number of the FIFs provides liquidity to the MGS market, and as most have relatively small allocations to MGS, they generally do not have resources to conduct high frequent transactions of MGS. Despite the large number of FIFs, their role in the market infrastructure should not be overstated. First, even the largest FIFs need the services provided by domestic market makers. Second, domestic banks are participating in a wide range of fixed-income instruments, which are either close substitutes of MGS (such as MGII) or similar to MGS though riskier (such as corporate bonds), while foreign investors actively participate in largely one segment of the fixed-income universe-MGS. Third, domestic banks are often the main buyers of MGS during the sell-offs of MGS by nonresidents. Therefore, a resilient domestic banking sector can always act as a buffer to the volatile capital flows carrying global liquidity sweeping in and out of the domestic financial market. 


\section{References}

Arslanalp, Serkan and Takahiro Tsuda, 2012, “Tracking Global Demand for Advanced Economy Sovereign Debt,” IMF Working Paper 12/284 (Washington: International Monetary Fund).

Arslanalp, Serkan and Takahiro Tsuda, 2015, "Emerging Market Portfolio Flows: The Role of Benchmark-Driven Investors", IMF Working Paper 15/263 (Washington: International Monetary Fund).

Bank Negara Malaysia, 2017, "Statement by Financial Markets Committee: Second Series of Initiatives to Develop the Onshore Financial Market," April 13, 2017.

Ebeke, Christian and Yinqiu Lu, 2015, "Emerging Market Local Currency Bond Yields and Foreign Holdings - a Fortune or Misfortune?" Journal of International Money and Finance, 59 (2015), 203-219.

International Monetary Fund, 2014, "Global Liquidity_-Issues for Surveillance.” ,2017, "Malaysia: 2017 Article IV Consultation-Press Release; Staff Report; and Statement by the Authorities of Malaysia," IMF Country Report No. 17/101 (Washington: International Monetary Fund).

,2018, "Malaysia: 2018 Article IV Consultation-Press Release; Staff Report; and Statement by the Executive Director for Malaysia," IMF Country Report No. 18/61 (Washington: International Monetary Fund).

J.P. Morgan, 2016, "Index Governance Recap: Rebalancing insight for Sukuk instruments entering EM indices on October $31^{\text {st }} \&$ November $30^{\text {th }}$," October 20, 2016, J. P. Morgan. ,2017a, “Index Governance Review,” May 2017. , 2017b, "Index Governance Review: 2017 review of the EM suite of indices," September 8, 2017, J. P. Morgan.

Lu, Yinqiu, and Dmitry Yakovlev, 2017, "Exploring the Role of Foreign Investors in Russia's Local Currency Government Bond (OFZ) Market," IMF Working Paper 17/28.

Peiris, Shanaka Jayanath, 2010, "Foreign Participation in Emerging Markets' Local Currency Bond Markets," IMF Working Paper 10/88.

Shek, Jimmy, Ilhyock Shim and Hyun Song Shin, 2015, "Investor redemptions and fund manager sales of emerging market bonds: how are they related?" BIS Working Papers No 509, August 2015. 
Shin, Hyun Song, 2012, "Global Banking Glut and Loan Risk Premium," IMF Economic Review, Vol. 60, Issue 2, pp. 155-192, 2012.

Templeton, 2017, “Templeton Global Fund, Monthly Commentary,” August 31, 2017. 


\section{Annex 1. Synthetic Exposure to Malaysian Fixed-Income Instruments}

This section provides an illustration of the mechanics of forming synthetic positions. In all the examples below we consider an interval spanning one month between $T_{0}$ and $T_{1}$. For simplicity, the yields and rates are expressed in the monthly basis; and the different yield conventions on different markets are ignored. The analysis is performed for a USDdenominated portfolio with the invested amount of dollar liquidity denoted by $V_{0}$. We consider only funded transactions, i.e., those that imply investing cash liquidity in cash bonds or bills at some steps during a transaction. The purely unfunded transactions are similar in nature, but are cashless and involve only derivatives.

\section{Case 1: Malaysian short-term instruments}

This is the simplest case of obtaining the pure FX exposure.

At $T_{0}$ the investor converts USD liquidity $V_{0}$ into the MYR on the spot market at the USDMYR exchange rate $S_{0}$ and obtains $V_{0} \cdot S_{0}$ units of MYR. Consequently, on the domestic Malaysian market the investor invests the proceedings into a short-term instrument yielding the short-term rate $r_{M Y R}$ and maturing in 1 month. Consequently, at $T_{1}$ the value of the investor's portfolio is equal to $V_{0} \cdot S_{0} \cdot\left(1+r_{M Y R}\right)$.

\section{Case 2: Synthetic short-term instruments}

At $T_{0}$ the investor invests USD liquidity $V_{0}$ into a USD-denominated short-term instrument yielding the short-term rate $r_{U S D}$ and maturing in 1 month. The value of this instrument at $T_{1}$ equals to $V_{0} \cdot\left(1+r_{U S D}\right)$.

In addition to this, at $T_{0}$ the investor engages in a forward FX contract to purchase MYR with settlements at $T_{1}$. The amount of USD liquidity to be sold is set to be $V_{0} \cdot\left(1+r_{U S D}\right)$ and thus the amount of the purchased MYR liquidity equals to $V_{0} \cdot\left(1+r_{U S D}\right) \cdot S_{F W D}$, where $S_{F W D}$ is the forward exchange rate for the pair USDMYR.

The amount of the MYR to be received could be rewritten by involving the FX-forward implied yield. The implied yield $r_{I Y}$ is defined as the solution to the following equation:

$$
S_{F W D}=\frac{1+r_{I Y}}{1+r_{U S D}} \cdot S_{0}
$$

Consequently, the amount of the MYR to be received may be written as $V_{0} \cdot S_{0} \cdot\left(1+r_{I Y}\right)$.

Table 1 summarizes all the components of the value of the investor's portfolio at $T_{1}$ (before netting out the legs of the FX forward). The total value equals to $V_{0} \cdot S_{0} \cdot\left(1+r_{I Y}\right)$ in MYR and differs from the case 1's terminal portfolio value only by the interest rate: $r_{I Y}$ instead of $r_{M Y R}$. 
Annex I. Table 1. Components of the Investor's Portfolio Terminal Value at $T_{1}$

\begin{tabular}{|c|c|c|}
\hline Instrument & $\begin{array}{c}\text { Value at } T_{1} \text { (in the units of the respective } \\
\text { currency) }\end{array}$ & Currency \\
\hline US Short-Term Instrument & $V_{0} \cdot\left(1+r_{U S D}\right)$ & \multirow{2}{*}{ USD } \\
\hline \multirow{2}{*}{ FX Forward } & $-V_{0} \cdot\left(1+r_{U S D}\right)$ & \\
\hline & $V_{0} \cdot S_{0} \cdot\left(1+r_{I Y}\right)$ & MYR \\
\hline
\end{tabular}

If the FX Forward is deliverable, then the investor's portfolio will have the expressed amount of the MYR liquidity.

\section{Case 3: Hedged investments in Malaysian bonds}

There are various techniques of FX-hedging a foreign currency bonds portfolio. In this example, we present a simplified scheme that demonstrates the core elements of any FXhedging methodology.

As in the case 1, we assume investing in domestic fixed-income instruments. Thus, at $T_{0}$ the investor converts USD liquidity $V_{0}$ into $V_{0} \cdot S_{0}$ units of MYR. The total MYR-denominated $\mathrm{P} \& \mathrm{~L}$ from the investments in Malaysian bonds during the period from $T_{0}$ to $T_{1}$ can be roughly approximated by the sum of the accrued interest components and the valuation gains and losses:

$$
\left[V_{0} \cdot S_{0} \cdot\left(1+Y_{M A L}\right)\right]+\left[-V_{0} \cdot S_{0} \cdot D_{M A L} \cdot \Delta Y_{M A L}\right]
$$

where $Y_{M A L}$ is the average yield of the purchased Malaysian bonds, $D_{M A L}$ is the average duration, and $\triangle Y_{M A L}$ is the change in yields (assuming a parallel shift of the yield curve). The accrued income at the yield $Y_{M A L}$ is composed of the accrued coupon income of bonds and the natural change in the bonds prices if they are traded below or above par.

In addition to buying the bonds, at $T_{0}$ the investor also engages into an FX forward contract to sell at $T_{1}$ the amount $V_{0} \cdot S_{0} \cdot\left(1+Y_{M A L}\right)$ of the MYR liquidity in order to receive the following amount of the USD liquidity:

$$
\frac{V_{0} \cdot S_{0} \cdot\left(1+Y_{M A L}\right)}{S_{F W D}}
$$

The components of the value of the portfolio at $T_{1}$ could be summarized in Table 2:

Annex I. Table 2. Components of the Investor's Portfolio Terminal Value at $T_{1}$

\begin{tabular}{c|c|c}
\hline Instrument & Value at $\boldsymbol{T}_{\mathbf{1}}$ (in the units of the respective currency) & Currency \\
\hline \multirow{3}{*}{ Malaysian local bonds } & $V_{0} \cdot S_{0} \cdot\left(1+Y_{M A L}\right)$ & \\
\cline { 2 - 2 } & $-V_{0} \cdot S_{0} \cdot D_{M A L} \cdot \Delta Y_{M A L}$ & \multirow{2}{*}{ MYR } \\
\hline \multirow{3}{*}{ FX Forward } & $-V_{0} \cdot S_{0} \cdot\left(1+Y_{M A L}\right)$ & \\
\cline { 2 - 3 } & $\frac{V_{0} \cdot S_{0} \cdot\left(1+Y_{M A L}\right)}{S_{F W D}}$ & USD \\
\hline
\end{tabular}


Given the definition of the implied yield, the amount of the USD liquidity to be received from the FX forward contract may be written as:

$$
V_{0} \cdot\left(1+r_{U S D}\right) \cdot \frac{1+Y_{M A L}}{1+r_{I Y}}
$$

or, using first-order approximations, as $V_{0} \cdot\left(1+r_{U S D}+\left[Y_{M A L}-r_{I Y}\right]\right)$.

The only remaining MYR-denominated component is the valuation gains and losses term: $-V_{0} \cdot S_{0} \cdot D_{M A L} \cdot \Delta Y_{M A L}$. Its USD equivalent is equal to

$$
\frac{-V_{0} \cdot S_{0} \cdot D_{M A L} \cdot \Delta Y_{M A L}}{S_{1}}=-V_{0} \cdot D_{M A L} \cdot \Delta Y_{M A L} \cdot(1+\delta)
$$

where $S_{1}$ is the USDMYR spot exchange rate at $T_{1}$, and $\delta=S_{0} / S_{1}-1$. If the hedging is conducted frequently, the value of $\left(\delta \cdot \Delta Y_{M A L}\right)$ is usually negligible. In any case, since the change $\triangle Y_{M A L}$ is an unexpected shock, the term at $\delta$ represents unavoidable minor exposure to the FX risk due to imperfect hedging.

Keeping only first order approximations (e.g., dropping $\delta \cdot \Delta Y_{M A L}$ ), we can write the value of the portfolio at $T_{1}$ as:

$$
V_{1}=V_{0} \cdot\left(1+r_{U S D}+\left[Y_{M A L}-r_{M Y R}\right]+\left[r_{M Y R}-r_{I Y}\right]+\left[-D_{M A L} \cdot \Delta Y_{M A L}\right]\right) .
$$

Thus, its rate of return $\left(\mathrm{V}_{1}-\mathrm{V}_{0}\right) / \mathrm{V}_{0}$ is a sum of the components from different markets. First, it has the US dollar short-term interest rate $r_{U S D}$. Second, it has an accrued income component earned at the rate equal to the term spread of the domestic Malaysian bonds market $\left[Y_{M A L}-r_{M Y R}\right]$. Third, it benefits from the difference $\left[r_{M Y R}-r_{I Y}\right]$ between the Malaysian domestic short-term rate and the NDF implied yield. Finally, it includes the component responsible for Malaysian domestic yield movements.

The rate of return may be presented as $r_{U S D}+D E X P_{M A L}$, i.e., the USD short-term rate plus the components of the separated pure duration exposure to the Malaysian bond market.

Further, it can be written as $r_{U S D}+D E X P_{U S T}+\left[D E X P_{M A L}-D E X P_{U S T}\right]$, where $D E X P_{U S T}$ is the total return from the exposure to the US Treasury bonds minus the short-term USD rate. Consequently, the total return from the fully FX-hedged position in Malaysian bonds may be expressed as:

$$
\text { [Performance of US Treasury bonds] + [Risk Add-On], }
$$

where [Risk Add-On $]=\left[D E X P_{M A L}-D E X P_{U S T}\right]$ reflects the relative impact of idiosyncratic developments in the US and Malaysian domestic bond markets as well as the relative supply of the duration risk. 